
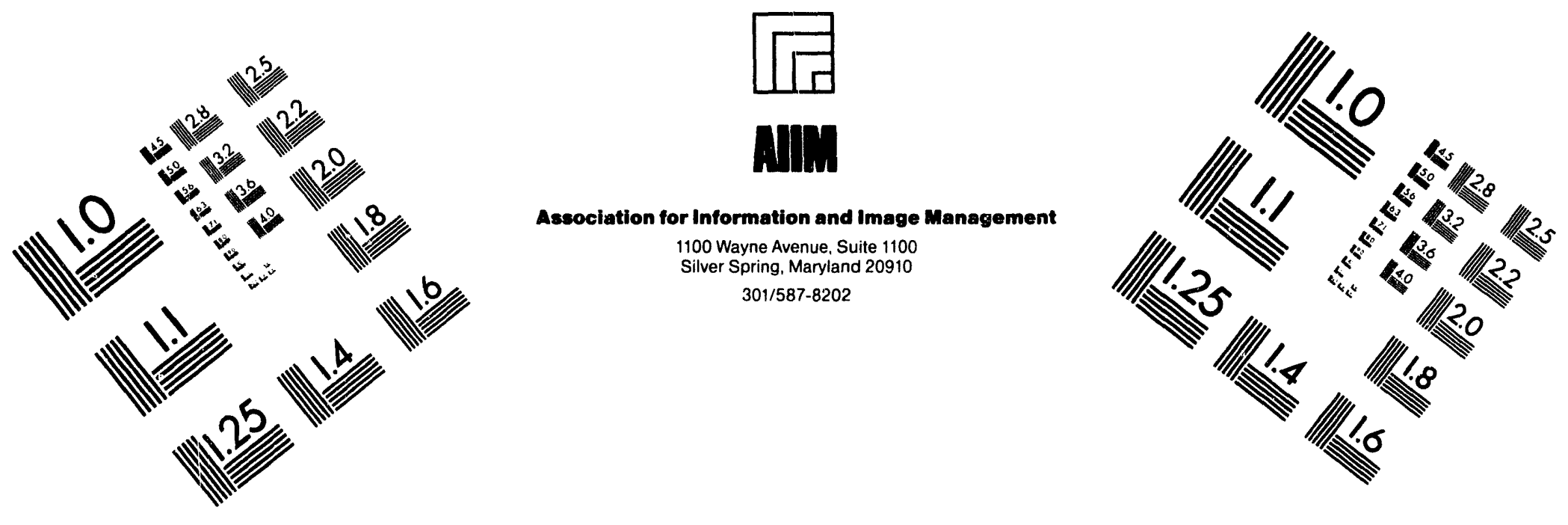

\title{
Centimeter
}

$\begin{array}{lllllllllllllll}1 & 2 & 3 & 4 & 5 & 6 & 7 & 8 & 9 & 10 & 11 & 12 & 13 & 14 & 15 \\ \mathrm{~mm}\end{array}$

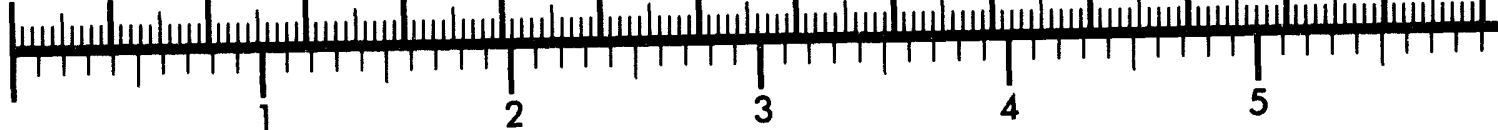
Inches
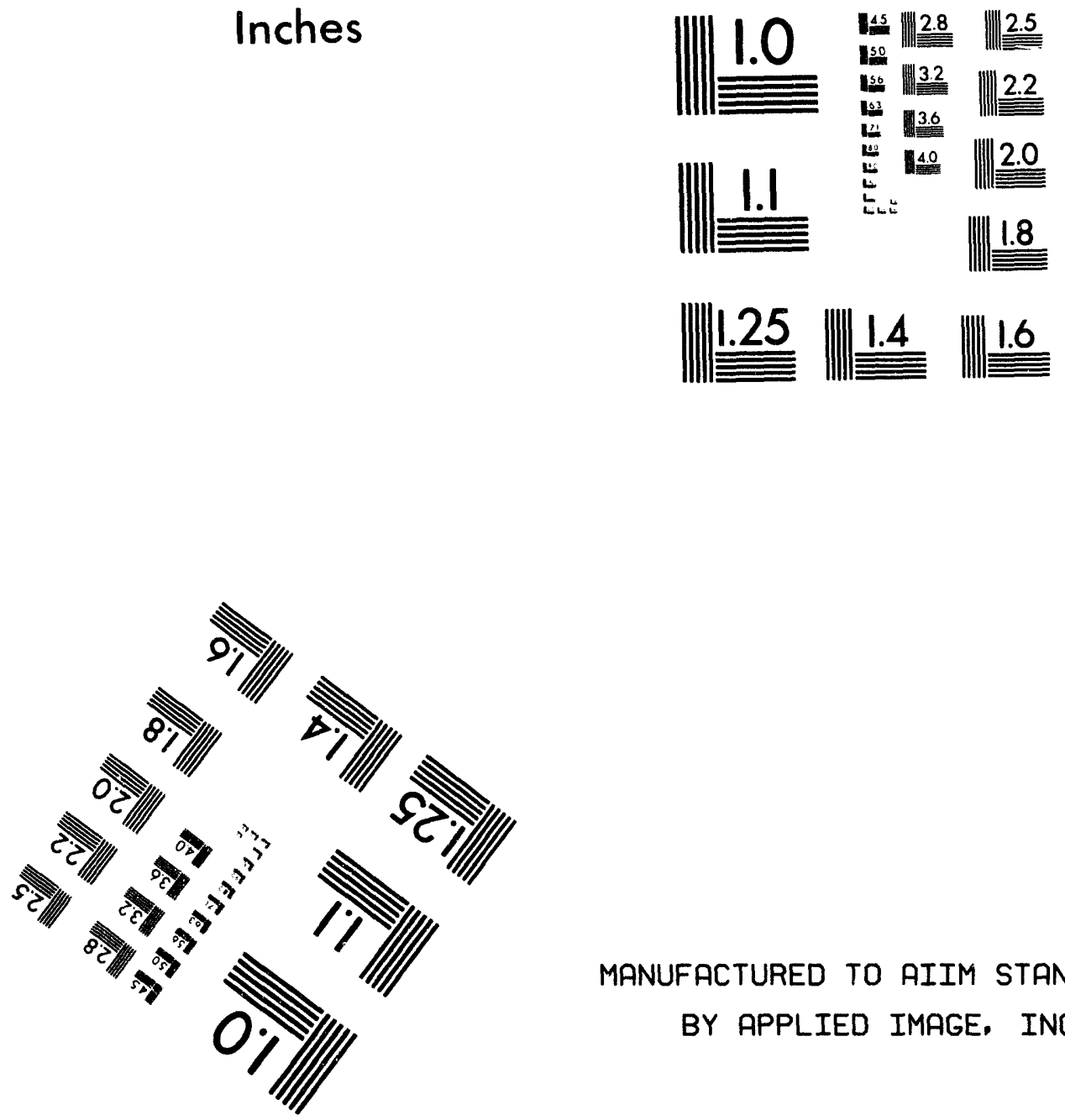

MANUFACTURED TO AIIM STANDARDS BY APPLIED IMAGE, INC.

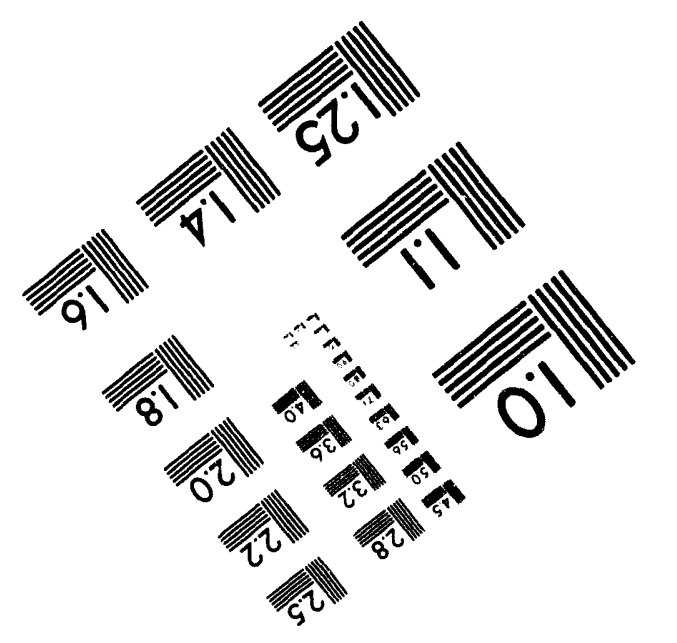



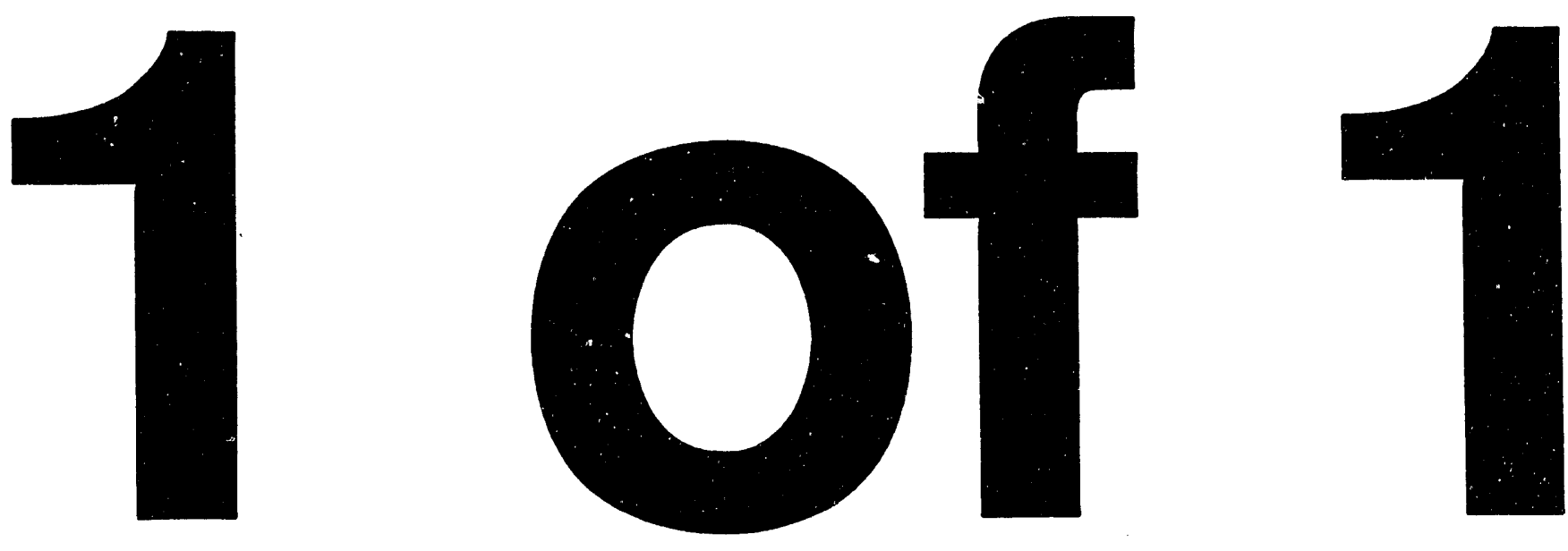
NUREG/CR-6212

BNL-NUREG-52413

\section{Value of Public Health and Safety Actions and Radiation Dose Avoided}

Manuscript Completed: April 1994

Date Published: May 1994

Prepared by

J. W. Baum
A. K. Roecklein, NRC Project Manager
B. J. Richter, NRC Technical Monitor

Brookhaven National Laboratory

Upton. NY 11973-5000

Prepared for

Division of Regulatory Applications

Office of Nuclear Regulatory Research

U.S. Nuclear Regulatory Commission

Washington, DC 20555-0001

NRC FIN A3259 


\begin{abstract}
The recent literature was reviewed for information on the cost per life saved in various health and safety activities, and the related value of dose avoided in radiation protection. In addition, agencies and organizations in several countries were contacted for information on the values being used or considered.

As expected, there is a wide range of values, reflecting the fact that the cost effectiveness of the safety options varies greatly depending on the nature of the risk. Another factor that affects costs is the need to achieve a safe environment (working or public) at escalating costs as safe limits are approached. This problem relates to societies', the courts', and regulators' preferences for avoiding inequitable distribution of risks; that is, no one individual should be expected to bear an unfair or excessive share of the risk. This preference leads to regulations that limit average individual risk to about $10^{-2}$ to $10^{-3}$ per lifetime in occupational exposures, and $10^{.3}$ to $10^{-6}$ in public exposures. The acceptable individual risk in the latter range depends on the number of individuals likely to be exposed.
\end{abstract}

The values judged best to reflect the willingness of society to pay for the avoidance or reduction of risk were deduced from studies of costs of health care, transportation safety, consumer product safety, government agency actions, wage-risk compensation, consumer behavior (market) studies, and willingness-to-pay surveys. The results ranged from $\$ 1,400,000$ to $\$ 2,700,000$ per life saved. Applying the mean of these values $(\$ 2,100,000)$ and the latest risk per unit dose coefficients used by the ICRP $(1991)$, which take into account risks to the general public, including genetic effects and non-fatal cancers, yields a value of dose avoided of $\$ 750$ to $\$ 1,500$ per person-cSv for public exposures. The lower value applies if adjustments are made for years of life lost per fatality. A nominal value of $\$ 1,000$ per person-cSv seems appropriate in light of the many uncertainties involved in deducing these values.

These values are consistent with values recommended by several European countries for individual doses in the region of $1 \mathrm{mSv} / \mathrm{y}$ ( $100 \mathrm{mrem} / \mathrm{y})$. Below this dose rate, most countries have values a factor of 7 to 10 lower, based on the assumption that society is less concerned with fatality risks below about $10^{-4} / \mathrm{y}$. 
FOREWORD

For approximately the last two decades, the NRC and its predecessor Agency the Atomic Energy Commission, have used a conversion factor of $\$ 1000$ per personrem as the monetary valuation of the benefits of avoided dose. With the passage of time, the NRC staff has become increasingly aware of alternative estimates and methodological approaches for arriving at a conversion factor. In the staff's view, a thorough reassessment of the dollar per person-rem value and its application in NRC regulatory decision making appears in order. At a minimum, the staff notes that two important changes, with potentially direct and significant impact on the $\$ 1000$ value have occurred. Inflation has caused the value of the dollar to continuously decrease, and estimates of risk coefficients have been revised upward.

The objective of this report is to provide the NRC with a review of the literature relating to regulatory agency use of a monetary valuation of person-rem averted, and the ciosely-related concept of the statistical value of 1 ife, in the U.S. and elsewhere. It includes recommendations and values used for a wide range of risks by other national and international organizations, and other U.S. Federal departments or agencies. The NRC is making use of this collected data in its decision to revise the dollar per person-rem conversion factor.

NUREG/CR-6212 is not a substitute for NRC regulations, and compliance is not required. The approaches and/or methods described in this NUREG are provided for information only. Publication of this report does not necessarily constitute NRC approval or agreement with the information contained herein.

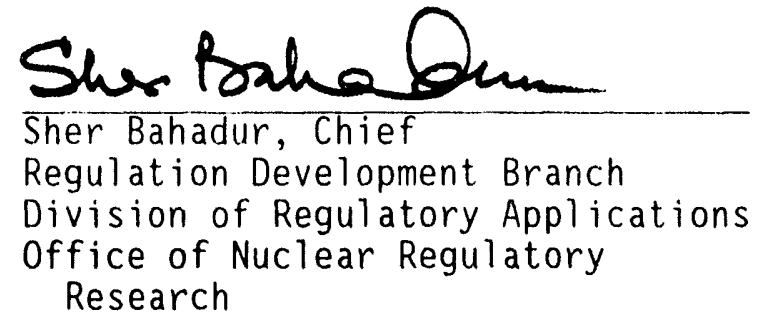




\section{Table of Contents}

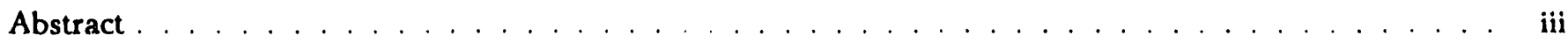

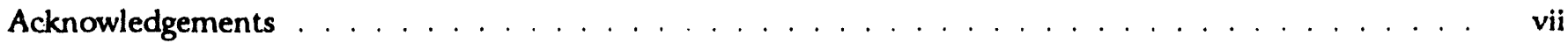

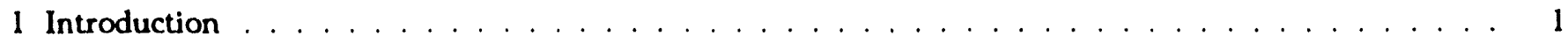

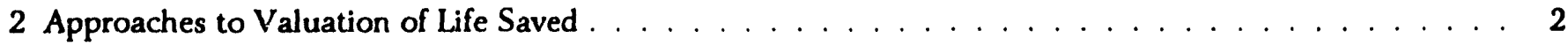

2.1 U.S. Health Care Actions . . . . . . . . . . . . . . . . . . . . . . . . . . . 4

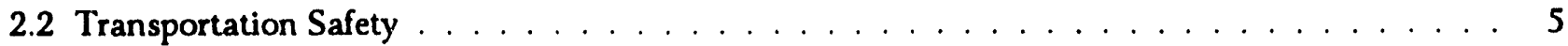

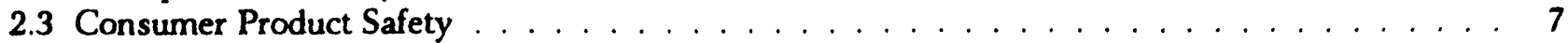

2.4 U.S. Government Agency Values . . . . . . . . . . . . . . . . . . . . . . . . 7

2.5 Wage-Risk Compensation . . . . . . . . . . . . . . . . . . . . . . 8

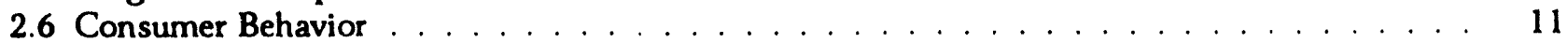

2.7 Chemical Carcinogen Regulation . . . . . . . . . . . . . . . . . . . . . . 12

2.8 WTP Surveys . . . . . . . . . . . . . . . . . . . . . . . . . . . . . . . . . 12

2.9 Risk Reducing Regulations . . . . . . . . . . . . . . . . . . . . . . . . . . . . . . . 16

2.10 Occupational Safety Actions . . . . . . . . . . . . . . . . . . . . . . . . 16

2.11 Cost Effectiveness of Radiation-Related Activities f . . . . . . . . . . . . . . . . . . . . . . . . 16

3 Quantitative Methods in Dose Control f . . . . . . . . . . . . . . . . . . . . 21

3.1 The Use of Cost-Benefit Analysis in Optimization of Radiation Protection . . . . . . . . . . . 21

3.2 National Radiological Protection Board (U.K) Recommendations . . . . . . . . . . . . . . . . 24

3.3 Valuation of Dose Avoided in France . . . . . . . . . . . . . . . . . . . . . . . . . . . . . . . 26

3.4 Values of Dose Avoided in U.S. Nuclear Power Plants . . . . . . . . . . . . . . . . . . . . . 27

3.5 Value of Dose Avoided and Proposed Rules Under Consideration in Sweden . . . . . . . . . . . 29

3.6 Recommended Values of Dose Avoided in Various Countries . . . . . . . . . . . . . . . . . . . . 29

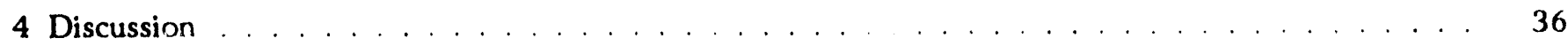

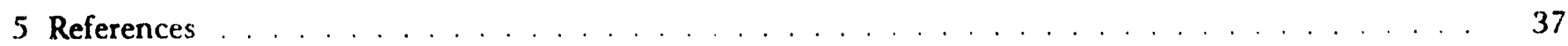

Figures

1 Schematic of Costs vs. Collective Doses . . . . . . . . . . . . . . . . . . . . . . . . . . . 22

2 Schematic of Cost Variations vs. Individual Doses . . . . . . . . . . . . . . . . . . . . . . . 23

3 Multiplier used by NRPB . . . . . . . . . . . . . . . . . . . . . . . . . . . . . . . . . . 25

4 Values of Dose Avoided in U.S. Nuclear Power Plants . . . . . . . . . . . . . . . . . . . . . . . . . 28

5 System of Dose Valuation Being Considered at Sydkraft Company in Sweden . . . . . . . . . . . . 30

6 The Band Scheme used by UKAEA . . . . . . . . . . . . . . . . . . . . . . . . . . . . . . 35 


\section{Tables}

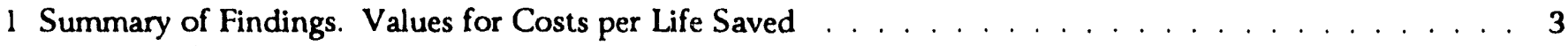

2 Costs of Life-Saving Actions in Health Care . . . . . . . . . . . . . . . . . . . . . . . . . . . . . 4

3 Cost Per Life Saved in Transportation Safety . . . . . . . . . . . . . . . . . . . . . . . . . 6

4 Cost Per Life Saved in Consumer Product Safety . . . . . . . . . . . . . . . . . . . . . . . . . 7

5 Values of Life Saved Used by U.S. Government Agencies . . . . . . . . . . . . . . . . . . . . . . . 9

6 Value of Life in Wage-Risk Studies _. . . . . . . . . . . . . . . . . . . . . . . . 10

7 Values of Life from Miller's (1990) "Sound" Studies of Consumer Behavior . . . . . . . . . . . . . . . . 13

8 Cost Effectiveness of Risk Reduction Due to Carcinogenic Chemicals . . . . . . . . . . . . . . . . . . . 14

9 Value-of-Life estimates Based on WTP Surveys . . . . . . . . . . . . . . . . . . . . . . . 15

10 The Costs of Various Risk-Reducing Regulations per Life Saved . . . . . . . . . . . . . . . . . 17

11 Costs of Life-Saving Actions in Occupational Safety . . . . . . . . . . . . . . . . . . . . . . . . . 19

12 Costs of Life-Saving Actions in Radiation-Related Activities . . . . . . . . . . . . . . . . . . . . . . . 19

13 NRPB Recommendations . . . . . . . . . . . . . . . . . . . . . . . . . . . . . . . 26

14 The EDF System for Occupational Exposures . . . . . . . . . . . . . . . . . . . . . . . . . . . . 27

15 Values of Dose Avoided Expressed in Equivalent 1990 U.S. Dollars . . . . . . . . . . . . . . . . 31 


\section{Acknowledgements}

The author thanks the following individuals for providing information for this study: R.H. Clarke, John D. Robb, and Frank Phillips (U.K.); Krister Egner, Bengt Lowendahl, and Christer Viktorsson (Sweden); Christian LeFaure, Jacques Lochard, and Philippe Rollin (France); J. Sinnaeve (CEC); Abel J. González and Geoff Webb (IAEA); Risto Paltemaa and Reijo Sundell (Finland); Shigeru Kumazawa (Japan); Giorgio N. Trenta (Italy); S.H. Yeh (Taiwan); Vaclav Hanusik (Slovak Republic); Wolfgang Pfeffer (Germany); and Ted Miller and Alan Richardson (U.S.).

The author thanks Sidney E. Feld, Clemens J. Heltemes, Jr., and Brian J. Richter of the U.S. Nuclear Regulatory Commission, and Charles B. Meinhold, Tasneem A. Khan, Darryl G.L. Kaurin, Bruce J. Dionne, Lin-Shen C. Sun, and Avril Woodhead of Brookhaven National Laboratory, for their critical reviews of the manuscript.

Sandra Sullivan provided valuable literature searches and retrieval; Grace A. Webster, Karen Rose, Maria C. Beckman, and Donna DeCaro typed the manuscript.

The study was done at the request of Alan K. Roecklein of the Nuclear Regulatory Commission as a task at the BNL ALARA Center under contract FIN A-3259. 


\section{Introduction}

In designing, licensing, constructing, operating, maintaining, decontaminating, and decommissioning major nuclear facilities, the regulatory agencies, operators, politicians, and public are confronted with several decisions related to the optimum balance between safety and the expenditure of resources.

For example, during the early planning stages, site selection is critical. Land costs, potentials for population exposures in accidents, hydrology, geology, meteorology, seismology, transportation, and population density all require careful consideration. During design and operation, many construction and equipment options related to safety must be evaluated, including analyses of potential accidents, their probabilities and severities, and the related emergency action plans, consequences, and costs.

An important element in the decision-making process is dose ${ }^{1}$ to the workers and the public. The costs of avoiding doses near and above the dose limits can be decisive in many cases. In addition, when a significant collective dose is involved, the health-effects costs become significant and must be evaluated, along with all other major costs, to arrive at optimum decisions which maximize the net benefits to society. The optimization of radiation protection is one of the three principal elements of the modern-day system of dose limitation developed and recommended by the International Commission on Radiological Protection (ICRP) (1973, 1977. 1983, 1989, 1991), and the National Committee on Radiation Protection and Measurement (NCRP) $(1987,1993)$. These principles are (1) justification of the practice, (2) optimization of radiation protection (keeping doses as low as reasonably achievable, ALARA), and (3) maintaining doses below the dose limits.

The dose limits are set to avoid acute radiation effects and to limit the risks of late effects to an acceptable level, which, for workers, is in the range below an annual risk of death of about 1 in 1,000

'Throughout this report the term "dose" is used generically and refers to either effective dose equivalent (effective dose in the latest ICRP terminology) or collective effective dose equivalent. $\left(10^{-3}\right)$. This value applies to normal operations, and might be higher during accidents. Below this is a region of tolerable risk, but risk to be avoided by applying the optimization process.

The ICRP published two reports that describe methods that may be used in implementing the quantitative aspects of the optimization process (ICRP, 1983, 1989). The most commonly used technique is differential (marginal) cost-benefit analysis. The results of a cost-benefit analysis are not usually sufficient for guiding a decision, but are important in identifying factors of importance, clarifying their relative importance, and providing a systematic, traceable flow of information for current and future decisions.

An important parameter in the quantitative optimization of radiation protection is the monetary value assigned to radiation detriment and to a related quantity that is referred to here as the value of dose avoided. Both are expressed in $\$$ per person-Sv, or $\$$ per person-rem and are discussed in the section on Optimization of Radiation Protection below. These values are needed for a complete cost-benefit analysis; however, the values employed and the costs included in their derivation vary greatly from one application to another, which has led to considerable confusion and debate in the radiation protection community and in the literature. The values employed in the nuclear industry and reviews of studies on value of life saved that provide a basis for some of these values were summarized by Baum (1991a, $199 \mathrm{lb}$ ) and Mubayi et al. (1992).

The objective of this paper is to clarify the use of the 'value of dose avoided' concept and to review values used or recommended by various organizations, as well as the related concepts of 'value of statistical life' or 'value of avoided fatality' (terms often shortened to 'value of life'). To make the values more comparable, they were adjusted for inflation using the variations in the consumer price index for all items (USDC, 1992) and expressed in equivalent 1990 dollars. All results have been rounded to two significant digits; however, the uncertainties are generally larger than implied by doing this. 


\section{Approaches to Valuation of Life Saved}

The minimum value of a life saved in health and safety studies often has been estimated from purely economic considerations. The simplest of these is the human capital approach in which the benefits of avoided death are assessed in terms of loss of production. The value of this productive benefit often is based on the lifetime earnings of the individual whose life is made safer. For individuals in the general public, this calculation is sometimes based on per capita gross domestic product (GDP), or per capita income. Additionally, an allowance typically is provided for the cost of medical care. For radiation exposures, consideration must be given to both somatic and hereditary effects.

In 1990, the average per capita income in the United States was about $\$ 50$ per day (USBC, 1992). The average value of a life saved then is calculated from the average lifespan shortening expected if the risk is not avoided. For typical radiation-induced cancers, this is about 15 years (ICRP, 1991), yielding a value of life saved of about 15 y $\times 365$ $\mathrm{da} / \mathrm{y} \times \$ 50 / \mathrm{da}=\$ 270,000$. Adding the costs of medical treatment would increase this figure by about 20\%, whereas discounting future earnings and costs could reduce the value by a similar or greater amount, depending upon the discount rate applied. In present-worth terms, based on a $3 \%$ discount rate, this value would decrease by $43 \%$. However, growth in GDP and standards of living tend to increase future values. Therefore, a lower, even zero, discount rate is often employed.

The human capital approach has many recognized shortcomings (Bequele, 1984). Most notably, critics argue it excludes allowances for pain, suffering, lost of enjoyment of life, and costs of medical treatment (however, this latter factor is often included). Also, there is value to family and community that is not reflected in GDP, and furthermore, an implicit (and unacceptable) implication that non-productive individuals (for example, retired and unemployed people) have no value or, perhaps, a negative one, if net earnings (i.e., net of consumption) are used to calculate human capital values.

The alternative willingness-to-pay (WTP) approach to valuation of risk reduction is aimed at determining societal preferences, and relating these to cost-benefit methodologies to optimize the decisions about allocation in the public sector. This approach is less easily quantified and, in the past, was criticized for the large uncertainties in the derived values. However, the U.K. Department of Transport recently issued a consultative document, Valuation o. Road A ccident Fatalities (DOT, 1992), in which they proposed that the Department's current procedure for valuing the avoidance of a fatality -based broadly upon the 'gross output' (or 'human capital') approach -. should be abandoned in favor of the WTP approach. It recommends that the value of a statistical life for transport risks be set at $£ 500,000$ (in 1987 prices), to be updated in line with increases in per capital national income. The value had increased to $£ 660,000$ in 1992 . This value is equal to about $\$ 1,300,000$ in 1990 U.S. dollars. Similarly, in the U.S., the Office of Management and Budget (OMB), which provides general guidelines on evolving regulatory actions, including those involving health and safety concerns, recommends the WTP approach (Miller, 1989).

Several studies were undertaken to determine the willingness of society to pay for risk reduction in various circumstances. The value arrived at depends on many factors including who pays (if society pays, it is less objectionable than if the individual at risk pays); whether risk is voluntary or involuntary (society usually expects that greater resources should be committed if exposure to risk is involuntary); the severity of the risk (the values are generally lower as risk/year increases); the risk-aversion characteristics of the individual at risk (some individuals are much more cautious and concerned with health and safety); the fear or dread associated with the risk; and, whether the person at risk is clearly identified (in contrast to a statistical probability of risk spread over a large population group), in which case, there is much greater WTP.

The recent literature was reviewed, and key individuals, agencies, and countries contacted to obtain up-to-date information on the value that is being used in decisions related to potential lifesaving actions, and the related values being assigned to dose avoidance in radiation- exposure environments. 
The results of these searches are summarized in the tables and figures in this report. To make this report brief and timely, the discussions in each area are limited. The reader may more fully understand the considerable efforts that were made in arriving at the current state of affairs by referring to the original reports. The results are thought to be reasonably coherent, considering the complexity of issues involved. In particular, various U.S. agencies appear to be moving to a common basis guided by the principles that agencies must first establish safe levels of exposure, and that cost-benefit analyses should only be used after the safe level is achieved. This philosophy has led many agencies to recommend limits that are very costly in terms of dollars per life saved because they were required to achieve a safe environment. Thus, some regulations are not cost effective, but are imposed to limit individual risk (for example, to $<10^{-3}$ per lifetime).
Other regulations are based on much lower risk levels that data indicate are achievable at reasonable cost (e.g., individual risks of $10^{.4}$ to $10^{6}$ fatalities per lifetime). Thus, large differences in cost effectiveness, as measured by dollars per life saved. are noted in the following results. It is important to recall the two different criteria (safe vs. as low as reasonably achievable) in reviewing the following data. Also, it is important to realize that some actions are exceptionally cost- effective and should certainly be encouraged, even perhaps mandated (e.g., seat-belt use) to ensure society is not burdened with unnecessary risks.

The results judged most relevant for estimating the value of dose avoided for public exposures are highlighted (in bold type) and underlined in Table 1 .

Table 1. Summary of Findings. Values for Costs per Life Saved*

\begin{tabular}{|c|c|c|c|}
\hline \multirow{2}{*}{ Subject } & \multicolumn{3}{|c|}{ Millions of 1990 Dollars } \\
\hline & Mean & Median & Maximum \\
\hline Health-care actions & 0.76 & 0.37 & 2.6 \\
\hline Transportation safety & 0.48 & 0.26 & 1.9 \\
\hline Consumer products safety & 0.56 & 0.49 & 1.4 \\
\hline $\begin{array}{l}\text { Values employed by U.S. } \\
\text { Government Agencies }\end{array}$ & 2.1 & 1.5 & 6.5 \\
\hline Wage/risk compensation ${ }^{c}$ & 2.4 & 2.5 & 3.7 \\
\hline Consumer behavior ${ }^{\mathrm{c}}$ & 2.3 & 2.2 & 3.4 \\
\hline Chemical carcinogen regulation & 6.4 & 2.9 & 16 \\
\hline WTP surveys ${ }^{c}$ & 2.7 & 2.7 & 3.9 \\
\hline Risk reducing regulations ${ }^{b}$ & 336 & 6.1 & 4400 \\
\hline Occupational safety & 22 & 9 & 85 \\
\hline Radiation related activities & 94 & 15 & 490 \\
\hline
\end{tabular}

"Values in bold are considered most reliable.

bValues c.e for the 14 final approved public regulations.

'Mean, median, and maximum values are based on Miller's (1990) data and analyses. 
Approaches

\subsection{U.S. Health Care Actions}

Cohen (1980) and Parsonage and Neuburger (1992) reviewed several examples of medical care which illustrated the high cost-effectiveness of many health-care actions. The latter authors expressed their results as quality-adjusted life years (QUALS) saved. To convert them to a value of a whole-life saved, their results were multiplied by 75.4 , which is the life expectancy for a person born in the United States in 1990. The results are summarized in
Table 2. Values of the estimated cost per fatality averted, expressed in 1990 dollars, range from $\$ 12,000$ for treatment of scoliosis and neuromuscular disease, to $\$ 2,600,000$ for kidney dialysis, which, on average, increases life expectancy about 9 years. A Federal program that guarantees treatment for patients with end-stage kidney disease as part of Medicare coverage enrolls about 45,000 patients a year at an average cost of $\$ 35,000$ per patient per year (N.Y. Times, 1993).

Table 2. Costs of Life-Saving Actions in Health Care

\begin{tabular}{||l|c||}
\hline \multicolumn{1}{|c|}{ Source: Parsonage and Neuburger (1992) } \\
\hline Hospital dialysis for kidney failure & Cost per Life (Millions of 1990 Dollars) \\
\hline Ambulatory dialysis for kidney failure & 2.6 \\
\hline CABG 1 vessel disease, moderate angina & 2.3 \\
\hline Nicotine gum for smokers male 35-9 & 1.1 \\
\hline Ceftazidime for cystic fibrosis & 1.0 \\
\hline Breast cancer screening & 0.87 \\
\hline Nicotine gum for smokers male 65-9 & 0.41 \\
\hline Renal transplant & 0.33 \\
\hline Shoulder joint replacement & 0.27 \\
\hline CABG severe angina, main vessel & 0.068 \\
\hline Teenage idiopathic scoliosis & $\begin{array}{c}\text { Median } \approx 0.37 \\
\text { Maximum }=2.6\end{array}$ \\
\hline Scoliosis + ne uromuscular disease & 0.068 \\
\hline & 0.033 \\
\hline
\end{tabular}

(Continued on next page) 
Table 2. Costs of Life-Saving Actions in Health Care (continued)

\begin{tabular}{|l|c|}
\hline \multicolumn{1}{|c|}{ Item } & Cost_per_ife (Millionsof_1990 Dollars) \\
\hline & Source: Cohen (1980) \\
\hline Hypertension control & 0.27 \\
\hline Screening for lung cancer & 0.26 \\
\hline Screening for cervical cancer & 0.092 \\
\hline Mobile intensive care unit & 0.065 \\
\hline Multiple screening & 0.056 \\
\hline Screening for colorectal cancer & 0.036 \\
\hline
\end{tabular}

-Values of costs per quality adjusted life years saved multiplied by 75.4 for total life expectancy (USBC, 1992).

${ }^{b}$ Cohen's values increased by a factor of 2.2 to adjust for inflation of medical costs to 1990 (USBC, 1992).

There are currently 195,000 Americarıs with kidney failure, and the number is expected to increase to 3 . 00,000 by the year 2000 . This treatment is, perhaps, the best example of willingness to pay for life extension when the individuals at risk are clearly identified and society pays the bill, for example, through insurance coverage. The value per life saved has not been adjusted for the poor quality of life that of ten accompanies the dialysis treatment, which includes nausea, flu-like symptoms, skin itches, pain in long bones, lack of appetite, and restricted diet. Most dialysis patients lose their jobs and must either spend 4 hours per day up to three times per week on a machine, be treated chemically and then drained up to four times a day, or be given a combination of the two treatments.

Many patients already are receiving these treat. ments, in spite of the fact that the overall medical costs are becoming a major concern. This fact suggests that this medical procedure is more representative of a realistic estimate of the willingness of society to pay to save a life at the margin. For this reason, this maximum value from Table 2 (rather than the median for all listed treatments) is highlighted in Table 1

\subsection{Transportation Safety}

Risk-reduction actions involving transportation were assessed in the United States by Cohen (1980) Costs per fatality averted are summarized in Table 3 , and range from $\$ 50,000$ per life saved for highway maintenance, to $\$ 1,900,000$ per life saved for use of driver-side airbags. The median value of cost effectiveness for the 12 items listed in Table 3 is about $\$ 260,000$ per life saved. However, over $2,654,000$ passenger cars came equipped with driver-side airbags in the United States in 1991 (National Safety Council, 1993), indicating that this may be near the margin of the value society is willing to pay for transportation safety. For this reason, this value has been highlighted in Table 1 . rather than the median value.

It is interesting to compare Table 3 to recent U.S costs per fatality of automobile accidents. For 1992, the National Safety Council (1993) estimated the economic cost per death to be $\$ 880,000$, related costs per injury were $\$ 50,000$. Comprehen sive cost estimates were included for the first time in the 1993 edition of Accident Facts (National Safety Council, 1993). These costs, including economic costs and a measure of the value of lost quality of 
Approaches

life associated with deaths and injuries, are indicative of what society is willing to pay to prevent them. Estimates based on this approach were given as $\$ 3,000,000$ per death and about $\$ 160,000$ per person injured, yet another indication of the growing acceptance in the United States of the WTP approach to risk-reduction valuations.

Table 3. Cost Per Life Saved in Transportation Safety"

\begin{tabular}{|c|c|}
\hline Item & Cost per Life (Millions of 1990 Dollars) \\
\hline \multicolumn{2}{|l|}{ Automobile Safety } \\
\hline Skid resistance & 0.11 \\
\hline Steering column improvement & 0.25 \\
\hline Passive seat belts & 0.63 \\
\hline Tire inspection & 1 \\
\hline Driver-side airbags & $1.9^{b}$ \\
\hline \multicolumn{2}{|l|}{ Traffic Safety } \\
\hline Highway maintenance & 0.05 \\
\hline Guardrail improvements & 0.085 \\
\hline Regulatory and warning signs & 0.085 \\
\hline Wrong-way entry avoidance & 0.13 \\
\hline Impact-absorbing roadside devices & 0.27 \\
\hline Median barrier improvement & 0.57 \\
\hline Clear roadside recovery area & 0.71 \\
\hline & $\begin{array}{c}\text { Mean }=0.48 \\
\text { Median } \approx 0.26 \\
\text { Maximum }=1.9\end{array}$ \\
\hline
\end{tabular}

'Cohen (1980)

bIncreased a factor of 2.4 (in addition to adjustment for inflation) over Cohen's value to adjust for more recent estimates of $11 \%$ reduction in fatalities for drivers of vehicles with safety belts and airbags compared to drivers of vehicles with safety belts and no airbags (National Safety Council, 1993). 


\subsection{Consumer Product Safety}

Table 4 summarizes eight cost-effective evaluations of consumer products that relate to safety. These values ranged from $\$ \mathbf{8 0 , 0 0 0}$ for smoke detectors in bedrooms only (Graham and Vaupel, 1983), to $\$ 1,400,000$ per life saved for safer fuel tanks and boilers. The studies summarized in this table illustrate the types of choices and range of values available to consumers. However, the highest value is judged as being the best indicator (from the set) of the willingness of society to pay for risk reduction.

\subsection{U.S. Government Agency Values}

Miller (1989) summarized values used between 1975 and 1988 by U.S. Government agencies, which were generally in the range of the $\$ 1,000,00$ to $\$ 2,000,000$ recommended by the OMB in 1985 ; however, an earlier value of about $\$ 5,000,000$ can be inferred from the Nuclear Regulatory Commission's recommendation (USNRC, 1975) to use $\$ 1,000$ per person-rem in the design phase of nuclear power plant systems, assuming a risk coefficient of one premature death per 5,000 person-cSv. This value is being re-evaluated in light of newer estimates of risk per unit dose and changing attitudes on the willingness of society to pay for risk reduction. Recently, the NRC issued new guidance for effluents from materials facilities in which the value $\$ 1,000$ per person-cSv was given as acceptable (USNRC, 1993). Using a public risk coefficient of $7.3 \times 10^{-4}$ per person-cSv, which reflects total stochastic risk (ICRP, 1991), implies a value of about $\$ 1,400,000$ (1993 dollars, or $\$ 1.2$ million in 1990 dollars) per fatality (or equivalent risk) avoided.

Table 4. Cost Per Life Saved in Consumer Product Safety

\begin{tabular}{||l|c|}
\hline \multicolumn{1}{|c|}{ Item } & Cost Per Life (Millions of 1990 Dollars) \\
\hline Smoke detectors in bedrooms only & 0.080 \\
\hline Mandatory smoke detectors & 0.12 \\
\hline Alcohol safety action projects & 0.16 \\
\hline Diet program & 0.20 \\
\hline Clothing flammability standard & 0.80 \\
\hline Safer fuel tanks and boilers & 1.4 \\
\hline \multicolumn{1}{|c|}{ Source for all the above: } & Graham and Vaupel (1983) \\
\hline Domestic smoke detectors (Dardis, 1980) & \begin{tabular}{c}
0.78 \\
\hline Cigarette smokers \\
(Ippolito and Ippolito, 1984)
\end{tabular} \\
\hline & $\begin{array}{c}0.93 \\
\text { Median } \approx 0.49 \\
\text { Maximum }=1.4\end{array}$ \\
\hline
\end{tabular}

Source: Sources as indicated in table, compiled by Mubayi et al. (1992). 
The EPA recommended values from about $\$ 1,600,000$ to $\$ 8,000,000$ for cleaning superfund sites (Miller, 1989), and made recommendations that reflect implicit values from about $\$ 200,000$ to $\$ 2,000,000$ per lung cancer averted by radon remediation of homes (USEPA, 1992). The lower value applies to homes having radon concentrations of $20 \mathrm{pCi} / \mathrm{L}$, whereas the higher value applies to homes near $4 \mathrm{pCil}$. Most State Department of Transportation agencies use values between $\$ 240,000$ and $\$ 360,000$ per life saved, whereas Arkansas, Nevada, New Mexico, Pennsylvania, and Texas use values from $\$ 1,000,000$ to $\$ 1,500,000$ (Miller, 1989).

The median of the ten values listed in Table 5 , expressed in 1990 dollars, is $\$ 1,500,000$ (or between $\$ 1$ million and $\$ 2$ million as recommended by OMB).

A range of values for agencies result, in part, from the variety of circumstances including differing degree of voluntariness, population size at risk, impairment before death, pain, and suffering.

\subsection{Wage-Risk Compensation}

One of the most thoroughly studied approaches to arriving at a value that workers place on their lives is to examine wage differentials in occupations of varying risks. The assumption, which has been accepted as valid since the time of Adam Smith (1776), is that risks, if known, will be compensated for by other benefits, the most obvious of these being a wage differential. Since the early 1970s, many systematic studies have been made and summarized, most recently and extensively by Fisher et al. (1989' Jones-Lee (1989), Miller (1990), and Viscusi (16

Miller (1990) identified 30 good quality studies, and 6 that he felt should not be included because of deficiencies for which he could not adequately make adjustments. To make the studies as comparable and consistent as possible, he converted all values to after-tax U.S. dollars, applied a common discount rate (2\%), and adjusted for differences in the definitions of risk variables; he also adjusted for excess risk associated with activities outside working hours, risk perception, and non-fatal risk.

Many wage-risk stuuics are based on data from the Bureau of Labor Statistics (BLS) data bases; these have data classified by industry. Several studies showed that models employing credible breakdowns of specific occupational groups (e.g., secretaries vs. production workers) within an industry yield riskcompensation values of life 2 to 5 times higher than those using BLS data with dummy variables that reflect the occupational characteristics of the industries (Miller, 1990). For example, dummy variables are needed to reflect the differences between risks to a janitor, clerk, factory production worker, ar d supervisor. Therefore, Miller divided by 3 the results obtained by Dorsey and Walzer (1983), Garen (1988), Leigh and Folsom (1984), Leigh (1987), Olson (1981). Smith (1974), Smith (1976), and Viscusi (1981) to adjust for their having used BLS data without industry-specific dummy-variable factors in their models.

Other major adjustments made by Miller include multiplying the results of Arnould and Nichols (1983), Brown (1980), and Thaler and Rosen (1976) by 2.2 to adjust for their using data from the Society of Actuaries, which did not distinguish between deaths on and off the job.

Table 6 also includes 25 studies reported by Viscusi (1992) who did not make the several adjustments made by Miller. Viscusi's summaries also include six studies not discussed by Miller. Four of these had values $>\$ 7,000,000$. The mean and median values for Miller's adjusted results are $\$ 2,400,000$ and $\$ 2,500,000$ per fatality averted, respectively; whereas, Viscusi gives the mean and median as $\$ 5,600,000$ and $\$ 4,600,000$, respectively. Thus, Miller's adjustments give lower values and less variability. They appear to be the best available synthesis of data on the value of avoided mortality based on wage-risk compensations; they are included in the Table 1 summary of findings, therefore. 
Table 5. Values of Life Saved Used by U.S. Government Agencies

\begin{tabular}{|c|c|c|c|}
\hline Agency & $\begin{array}{l}\text { Original Value } \\
\text { (Millions of } \\
\text { Dollars) }\end{array}$ & $\begin{array}{c}\text { Year } \\
\text { Adopted }\end{array}$ & $\begin{array}{c}\text { Value } \\
\text { Adjusted } \\
\text { to } 1990 \\
\text { (Millions of } \\
\text { Dollars) } \\
\end{array}$ \\
\hline $\begin{array}{l}\text { Nuclear Regulatory Commission (USNRC, } \\
\text { 1993c) }\end{array}$ & 1.4 & 1993 & 1.2 \\
\hline Consumer Pro luct Safety Commission & $1.5-2^{*}$ & 1981 & $2.6^{\mathrm{c}}$ \\
\hline Occupational Safety \& Health Administration & $2 \cdot 3.5^{\circ}$ & 1983 & 3.7 \\
\hline Office of Management \& Budget & $1-2^{*}$ & 1985 & $1.8^{\mathrm{c}}$ \\
\hline Environmental Protection Agency & $1.6-8^{\circ}$ & 1983 & $\approx 6.5$ \\
\hline $\begin{array}{l}\text { Environmental Protection Agency } \\
\text { Home Radon Remediation (USEPA, 1992) }\end{array}$ & $0.7^{b}$ & 1992 & $0.6^{b}$ \\
\hline Department of Transportation & $1 \cdot 1.5^{\circ}$ & 1986 & $1.5^{\mathrm{c}}$ \\
\hline Department of Agriculture & $1.1^{\bullet}$ & 1985 & 1.3 \\
\hline Most State Department of Transportation & $0.24-0.36^{*}$ & $\cdots$ & $0.3^{c}$ \\
\hline $\begin{array}{l}\text { AK, NV, NM, PA, TX Department of } \\
\text { Transportation }\end{array}$ & $1-1.5^{\circ}$ & $1987-1988$ & 1.4 \\
\hline & & \multicolumn{2}{|c|}{$\begin{array}{c}\text { Mean } \approx 2.1 \\
\text { Median } \approx 1.5 \\
\text { Maximum } \approx 6.5\end{array}$} \\
\hline
\end{tabular}

'Values reported by Miller (1989).

'This value depends on initial concentration and varies from about $0.2 \mathrm{M}$ for an action level of $20 \mathrm{pCi} / \mathrm{L}$ to about $2 \mathrm{M}$ at $4 \mathrm{pCi} / \mathrm{L}$ for existing homes; lower costs would be incurred for radon control in new home construction.

The Consumer Product Safety Commission currently recommends $\$ 2,000,000$ and is considering $\$ 3,000,000$; $\mathrm{OMB}$ is now routinely accepting $\$ 2,000,000$ to $\$ 5,000,000$; the Department of Transportation currently recommends $\$ 2,400,000$ and most state Departments of Transportation recommend between $\$ 1,500,000$ and $\$ 2,400,000$ (T.D. Miller, personal communication, 1994) 
Table 6. Value of Life in Wage-Risk Studies

\begin{tabular}{|c|c|c|c|}
\hline \multirow[b]{2}{*}{ Study } & \multirow{2}{*}{$\begin{array}{l}\text { Wage Data } \\
\text { Year }\end{array}$} & \multicolumn{2}{|c|}{ (Millions of 1990 Dollars) } \\
\hline & & $\begin{array}{c}\text { Miller } \\
\text { (1990) }\end{array}$ & $\begin{array}{l}\text { Viscusi } \\
\text { (1992) }\end{array}$ \\
\hline Arnould and Nichols (1983) & 1970 & 1.6 & 0.9 \\
\hline Brown (1980) & $1966-71$ & 2.9 & 1.5 \\
\hline Butler (1983) & $1940-69$ & 1.2 & 1.1 \\
\hline Cousineau et al. (1988) & 1979 & 3.1 & 3.6 \\
\hline Dickens (1984) & 1977 & 2.6 & \\
\hline Dillingham and Smith (1984) & 1979 & 3.7 & \\
\hline Dillingham (1985) & 1970 & 1.8 & \\
\hline$" \quad n$ & 1977 & 2.6 & $2.5 \cdot 5.3$ \\
\hline Diliingham and Miller (1990) & 1977 & 3.2 & \\
\hline Dorsey and Walzer (1983) & 1978 & 2.9 & \\
\hline Garen (1988) & $1981-82$ & 1.8 & 13.5 \\
\hline Gegax et al. (1987) & 1983 & 1.5 & \\
\hline Herzog and Schlottman (1987) & 1970 & & 9.1 \\
\hline Kniesner and Leeth (1991) & 1986 (Japan) & & 7.6 \\
\hline$"$ & $\begin{array}{l}1984-85 \\
\text { (Australia) }\end{array}$ & & 3.3 \\
\hline$n$ & $1978(U S)$ & & 0.6 \\
\hline Leigh and Folsom (1984) & 1974 & 2.4 & 9.7 \\
\hline$n \quad " n$ & 1977 & 2.6 & 10.3 \\
\hline Leigh (1987) & 1977 QES & 3.1 & 10.4 \\
\hline$n$ & 1977 CPS & 1.9 & \\
\hline $\begin{array}{l}\text { Marin and Psacharopoulus } \\
(1982)\end{array}$ & 1975 & 2.6 & 2.8 \\
\hline Melinek (1974) & 1971 & 1.5 & \\
\hline Moore and Viscusi (1988a) & 1981 & 2.9 & 2.5 \\
\hline
\end{tabular}

(Continued on next page) 
Table 6. Value of Life in Wage-Risk Studies (continued)

\begin{tabular}{|c|c|c|c|}
\hline \multirow[b]{2}{*}{ Study } & \multirow{2}{*}{$\begin{array}{c}\text { Wage Data } \\
\text { Year }\end{array}$} & \multicolumn{2}{|c|}{ (Millions of 1990 Dollars) } \\
\hline & & $\begin{array}{c}\text { Miller } \\
\text { (1990) }\end{array}$ & $\begin{array}{l}\text { Viscusi } \\
\text { (1992) }\end{array}$ \\
\hline Moore and Viscusi (1988b) & 1977 & & 7.3 \\
\hline $\begin{array}{l}\text { Moore and Viscusi } \\
(1990 \mathrm{a}, 1990 \mathrm{~b})\end{array}$ & 1982 & & 16.2 \\
\hline Olson (1981) & 1973 & 3.0 & 5.2 \\
\hline R.S. Smith (1974) & 1967 & 3.2 & 7.2 \\
\hline R.S. Smith (1976) & 1973 & 1.4 & 4.6 \\
\hline V.K Smith (1983) & 1978 & 2.1 & \\
\hline V.K Smith and Gilbert (1984) & 1978 & 2.0 & 0.7 \\
\hline Thaler and Rosen (1976) & 1967 & 1.6 & 0.8 \\
\hline Viscusi $(1978 \mathrm{a}, 1978 \mathrm{~b})$ & $1969-70$ & 2.4 & 4.1 \\
\hline Viscusi $(1980)$ & 1969.70 & 3.0 & \\
\hline Viscusi (1981) & 1976 & 2.0 & 6.5 \\
\hline Viscusi and Moore (1988) & 1976 & 1.7 & \\
\hline \multirow[t]{4}{*}{ Viscusi and Moore (1989) } & 1981 & 3.1 & 7.8 \\
\hline & Mean & $2.4 \pm 0.7$ & $5.6 \pm 4.1$ \\
\hline & Median & 2.5 & 4.6 \\
\hline & Maximum & 3.7 & 16.2 \\
\hline
\end{tabular}

Wage-risk compensation as a basis for evaluating risk avoidance has limitations due to inaccuracies about workers' ability to change occupations freely if risks are of concern.

\subsection{Consumer Behavior}

Consumers have many choices in everyday life, which can be used to help in judging their values of risk avoidance and willingness to pay for risk reduction.
These choices were discussed by Cohen (1980), Jones-Lee (1989), and Miller (1990). Miller reviewed literature from the 1970s and 1980s and rejected four studies as unreliable as superseded by better ones. In addition, he recomputed and made several adjustments to make the studies more consistent in their assumptions and factors considered. Eleven adjusted sound studies are given in Table 7, with values increased by $10 \%$ over those given by Miller in 1988 dollars. The values of life saved in Table 7 range only from $\$ 1,100,000$ to 
$\$ 3,400,000$, which is surprising in light of the variety of topics covered and the ranges reflected in Tables 2, 3, and 4, which cover some of the same topics. The differences between the tables may reflect differences in quality of some of the data, the wider range of topics considered in Tables 2,3 , and 4 , the lack of consistent treatment of data in some of the data in Tables 2, 3, and 4, and differences in costs of mandated, regulated, or governmentcontrolled options.

The mean and median values of life-saving actions are both $\$ 2,300,000$ and $\$ 2,200,000$, respectively, for the results of consumer behavior shown in Table 7.

\subsection{Chemical Carcinogen Regulation}

Travis et al. (1987a,b) reviewed the risks and costs associated with 90 U.S. regulations and over 130 uses of chemical carcinogens. Table 8 summarizes the cost effectiveness of regulations on 11 typical chemical products and 5 processes which affect the public, such as soil fumigation. Values per fatal cancer avoided range from $\$ 40,000$ to $\$ 210,000,000$, expressed in 1990 dollars. To obtain these costs, Travis et al. used a $10 \%$ discount rate and 15-year payback period for annual operational costs and capital costs. The median cost for the 11 chemical products listed in Table 8 is $\$ 2,900,000$.

These authors concluded that when lifetime cancer risk exceeded about $4 \times 10^{-3}$, chemicals were regulated regardless of cost (Travis et al., 1987b). For chemicals with lifetime risks from $10^{6}$ to $4 \mathrm{x}$ $10^{-3}$, if costs per life saved were less than $\$ 2,000,000$, regulations were implemented, but if such costs were greater than $\$ 2,000,000$, the regulations were not implemented. These conclusions were not always consistent with the later studies of Viscusi (1992), summarized in Table 9 and discussed below.

\subsection{WTP Surveys}

In contrast to studies of consumer behavior, which evaluate the willingness of society to pay for risk reduction based on actual market studies, the techniques of WTP surveys elicit responses to questions that postulate hypothetical market choices. The respondents are presented with material, often during a personal interview, that includes a detailed description of the goods being valued and the circumstances under which they are made available. Respondents are queried on the price they would be willing to pay for the goods, as well as their personal characteristics (e.g., age, income). The questions are carefully designed to minimize bias by the question or questioner. Various techniques are used to randomize the sample and eliminate data of poor quality.

Jones-Lee (1989), Miller (1990), and Viscusi (1992) recently reviewed survey results. Miller (1989) classified 6 of the 15 surveys reviewed as sound. Nine surveys were omitted because of design problems, lack of realistic markets, minute risks that elicit unrealistic responses, pilot studies, or unclear risks. Table 9 summarizes Miller's (1989) and Viscusi's (1992) results. The results of Jones-Lee (1976) on airline safety is an example of one ruled out by Miller because it was a pilot study. Miller ruled out Acton's study (1973) because of the number of irrational responses, suggesting problems in design; also, the survey was limited to 36 people. In the U.K., Jones-Lee (1989) found that the value per life saved was $\$ 3,000,000$ in WTP studies involving a large survey ( 1,150 persons) in which car and coach (bus) safety questions and interviews by professional interviewers were employed.

The results of these surveys yield median values of willingness to pay for fatal risk reduction of $\$ 2,700,000$ (Miller) and $\$ 3,100,000$ (Viscusi) per life saved. Again, the range of values in Miller's summary is small ( $\$ 1.6$ million to $\$ 3.9$ million), partly due to his selection of sound surveys. The values from Miller's analyses are judged the best and, therefore, included in the Table 1 summary. 
Table 7. Values of Life from Miller's (1990) "Sound" Studies of Consumer Behavior

\begin{tabular}{|c|c|c|c|c|}
\hline Study & Subject & $\begin{array}{c}\text { Risk } \\
\text { Level }^{c}\end{array}$ & $\begin{array}{l}\text { Published } \\
\text { Value }^{d}\end{array}$ & $\begin{array}{c}\text { Revised } \\
\text { and Risk } \\
\text { Adjusted } \\
\text { Valued } \\
\text { (Millions of } \\
1990 \text { Dollars) }\end{array}$ \\
\hline Blomquist (1979) & Seat belt use & 3.0 & 0.66 & 2.1 \\
\hline Blomquist and Miller (1990) & Seat belt use & 1.6 & 1.9 & 3.4 \\
\hline Ghosh, Lees, and Seal (1975) & Speeding UK & $?$ & 0.61 & 2.4 \\
\hline Ippolito and Ippolito (1984) & Smoking & $650-1370$ & $0.26 \cdot 1.4$ & $1.1^{*}$ \\
\hline Jondrow, Bowes and Levy (1983) & Speeding & 1.5 & $\ldots$ & 1.4 \\
\hline Landefeld and Seskin (1982) & Life insurance & 49 & 0.96 & 3.2 \\
\hline Melinek (1974) & Use of pedest walk, UK & .05 & 1.5 & 2.2 \\
\hline Miller (1990) & Smoke detectors & .9 & $\cdots$ & 1.8 \\
\hline Miller (1990) & Wage rate & NA & 2.1 & 2.2 \\
\hline Smith and Gilbert (1984) & Jobs in unpolluted cities & $?$ & $2.2-4.1$ & $2.8^{\mathrm{b}}$ \\
\hline \multirow[t]{2}{*}{ Winston and Mannering (1984) } & Auto safety features & 1.2 & $\ldots$ & 2.7 \\
\hline & & & $\begin{array}{c}\text { Mean } \\
\text { Median } \\
\text { Maximum }\end{array}$ & $\begin{array}{l}\approx \$ 2.3 \\
\approx \$ 2.2 \\
\approx \$ 3.4\end{array}$ \\
\hline
\end{tabular}

"Values are underestimates because they do not completely account for the addictive nature of heavy smoking.

'Values adjusted because the entire family realizes the risk reduction benefits.

Risks are in units of 1 in 10,000 .

'Values in millions of after-tax dollars rounded to two significant digits. 
Table 8. Cost Effectiveness of Risk Reduction Due to Carcinogenic Chemicals

\begin{tabular}{|c|c|}
\hline Chemical & $\begin{array}{c}\text { Cost Per Life-Saved } \\
\text { (Millions of } 1990 \text { Dollars) } \\
\end{array}$ \\
\hline \multicolumn{2}{|l|}{ Products } \\
\hline Lead & 1.9 \\
\hline Asbestos (Occupational) & 4.2 \\
\hline Vinyl chloride & 16 \\
\hline Formaldehyde (Public) & 2.9 \\
\hline Trihalomethane & 0.24 \\
\hline Butadiene & 0.2 \\
\hline Cadrnium & 1.2 \\
\hline Chromium & 0.04 \\
\hline Chlorobenzilate & 25 \\
\hline Ethylene oxide & 4.7 \\
\hline Benzene & 14 \\
\hline \multicolumn{2}{|l|}{ Processes (Public Exposures) } \\
\hline Soil fumigation & 0.87 \\
\hline Quarantine fumigation & 0.12 \\
\hline Glass manufacturing & 110 \\
\hline Low-arsenic copper smelting & 210 \\
\hline High-arsenic copper smelting & 2.1 \\
\hline & $\begin{array}{c}\text { Mean }=6.4 \\
\text { Median }=2.9 \\
\text { Maximum }=16\end{array}$ \\
\hline
\end{tabular}

Source: Travis et al. $(1987 \mathrm{a}, \mathrm{b})$

'Exception is Benzene (Nicholson and Landrigan, 1989) 
Table 9. Value-of-Life estimates Based on WTP Surveys (Millions of 1990 Dollars)

\begin{tabular}{|c|c|c|c|c|}
\hline Study & Subject & Country & $\begin{array}{c}\text { Miller } \\
(1990)^{*}\end{array}$ & $\begin{array}{l}\text { Viscusi } \\
(1992)^{b} \\
\text { or } \\
\text { Jones- } \\
\text { lee } \\
(1989)^{c}\end{array}$ \\
\hline Gerking et al. (1988) & Job fatality risk & U.S.A. & 2.4 & 3.4 \\
\hline Jones-Lee (1976) & Airline safety $(n=30)$ & U.K & $\ldots$ & 15.6 \\
\hline Jones-Lee (1989) & $\begin{array}{l}\text { Motor vehicle accidents } \\
(n=1,150)\end{array}$ & U.K. & 3.0 & 3.8 \\
\hline Landefeld (1979) & Cancer & U.S.A. & 2.8 & $\ldots$ \\
\hline Maclean (1979) & Fire safety $(n=325)$ & U.K. & 3.9 & $4.7^{c}$ \\
\hline Melinek (1974) & Safer cigarettes $(n=830)$ & U.K. & $\cdots$ & $0.15^{\mathrm{c}}$ \\
\hline Miller and Guria (1991) & Traffic safety & $\begin{array}{l}\text { New } \\
\text { Zealand }\end{array}$ & $\cdots$ & 1.2 \\
\hline Acton (1973) & $\begin{array}{l}\text { Improved ambulance service } \\
\text { for heart attacks }(n=36)\end{array}$ & U.S.A. & $\ldots$ & 0.1 \\
\hline Persson (1989) & Highway safety & Sweden & 1.6 & $\ldots$ \\
\hline $\begin{array}{l}\text { Viscusi et al. } \\
(1989,1991) \\
\end{array}$ & $\begin{array}{l}\text { Auto risk - living cost } \\
\text { trade-off }\end{array}$ & U.S.A. & 2.6 & 2.7 \\
\hline & Mean & & 2.7 & 4.0 \\
\hline & Median & & $\approx 2.7$ & $\approx 3.1$ \\
\hline & Maximum & & 3.9 & 15.6 \\
\hline
\end{tabular}

aMiller's (1988) values adjusted for inflation and rounded to two significant figures.

bViscusi (1992)

'Based on Jones-Lee (1989), not cited by Viscusi. 


\subsection{Risk Reducing Regulations}

Morrall (1986) reviewed literature on 44 federal health and safety regulations and rules for which there was fairly comprehensive information on risks and costs. Table 10 summarizes Viscusi's (1992) update of the cost effectiveness and status of 33 rules that were either finalized, proposed, or rejected. Eight proposed rules (seven EPA and one OSHA) were rejected. In his analysis, Morrall adjusted costs for non-fatal injuries using 50 nonfatal hospitalizations avoided, or two permanent disabilities avoided as equal to one fatality. Unstated monetary values, based on leading economic studies of individuals' willingness to pay for avoided fatalities, were subtracted from other costs to provide a net cost-effectiveness value per life saved. Morrall also applied a $10 \%$ discount rate to both costs and benefits that occur at later times, and adjusted some agency assumptions that he considered overly optimistic. He believed that many of the risk and cost-effectiveness figures in the table are overstated, especially for cancer-reducing rules. Results per life saved ranged from $\$ 130,000$ for action on unvented space heaters (a CPSC rule) to $\$ 91,000,000,000$ for regulations on formaldehyde (an OSHA rule). The median value per life saved for the 24 rules that were finalized was about $\$ 5,100,000$. The median value for the 14 public safety rules (CPSC, FAA, NHTSA, FDA, and EPA) that were finalized was about $\$ 6,100,000$.

Thirteen EPA rejected or final rules have costeffectiveness values above the upper value of $\$ 11,000,000$ implied in Table 5 (\$8 million increased to $\$ 11$ million to account for inflation to 1990) as an upper value for the EPA range. Six OSHA rejected or final rules are above the upper value of $\$ 4,800,000$ per life saved implied in Table 5 (\$3.5 million increased to $\$ 4.8$ million to account for inflation to 1990). These high values may reflect deviations from the cost-effectiveness or the criterion as low as reasonably achievable. The higher values may be dictated by the requirement that agencies first establish a safe level (U.S. Supreme Court, 1980). For this reason, results based on the costs associated with meeting regulations are not considered a good measure of the willingness of society to pay for risk reduction at the margin.

\subsection{Occupational Safety Actions}

Cohen (1980) and Graham and Vaupal (1981) evaluated and summarized information on costs per life saved in various industries. The results for eight evaluations are summarized in Table 11 . They range from $\$ 1,300,000$ per life saved for adding sulfur scrubbers in coal-fired power plants, to $\$ 85,000,000$ per life saved for mine safety actions. The median value for these studies was $\$ 9,000,000$ per life saved. Some high values may result from actions needed to achieve a safe working environment (at any cost), rather than through application of the cost-effectiveness criterion.

\subsection{Cost Effectiveness of Radiation-Related Activities}

Cohen (1980) evaluated the cost-effectiveness of several radiation-related activities, which are summarized in Table 12, along with values deduced from EPA guidance on radon remediation. The cost effectiveness of radon remediation varies with the initial concentrations because additional benefits result from reducing higher exposures. At the recommended remediation limit of $4 \mathrm{pCi} / \mathrm{L}, \mathrm{EPA}$ estimates cost effectiveness to be about $\$ 700,000$ per fatality averted (Page, 1993). The risks depended not only on exposures, but also on smoking habits of the exposed individuals, with smokers having about eight times higher risk per unit exposure. This recommended voluntary expenditure is in sharp contrast to the costs of radioactive waste disposal of up to $\$ 490,000,000$ per life saved cited by Cohen (1980). This difference illustrates the need for greater consistency in the decision-making process and greater understanding of relative risks on the part of the public. The mean and median values of $\$ 94,000,000$ and $\$ 15,000,000$, respectively, per life saved for these activities are inconsistent with others cited earlier. 
Table 10. The Costs of Various Risk-Reducing Regulations per Life Saved

\begin{tabular}{|c|c|c|c|c|}
\hline Regulation & $\begin{array}{l}\text { Year } \\
\text { and } \\
\text { status }\end{array}$ & Agency & $\begin{array}{l}\text { Annual } \\
\text { lives } \\
\text { saved }\end{array}$ & $\begin{array}{l}\text { Cost per } \\
\text { life saved } \\
\text { (Millions } \\
\text { of } 1990 \\
\text { Dollara) }\end{array}$ \\
\hline Unvented space heaters & $1980 \mathrm{~F}^{b}$ & CPSC & 63.00 & .13 \\
\hline Oil and gas well service & $1983 \mathrm{P}$ & OSHA-S & 50.00 & .13 \\
\hline Cabin fire protection & $1985 \mathrm{~F}$ & FAA & 15.00 & .25 \\
\hline Passive restraints/belts & $1984 \mathrm{~F}$ & NHTSA & $1,850.00$ & .38 \\
\hline Underground construction & $1989 \mathrm{~F}$ & OSHA-S & 8.10 & .38 \\
\hline Alcohol and drug control & $1985 \mathrm{~F}$ & FRA & 4.20 & .63 \\
\hline Servicing wheel rims & $1984 \mathrm{~F}$ & OSHA.S & 2.30 & .63 \\
\hline Seat cushion flammability & $1984 \mathrm{~F}$ & FAA & 37.00 & .76 \\
\hline Floor emergency lighting & $1984 \mathrm{~F}$ & FAA & 5.00 & .88 \\
\hline $\begin{array}{l}\text { Crane-suspended personnel } \\
\text { platform }\end{array}$ & $1988 \mathrm{~F}$ & OSHA-S & 5.00 & 1.5 \\
\hline Concrete and masonry construction & $1988 \mathrm{~F}$ & OSHA.S & 6.50 & 1.8 \\
\hline Hazard communication & $1983 \mathrm{~F}$ & OSHA-S & 200.00 & 2.3 \\
\hline Benzene/fugitive emissions & $1984 \mathrm{~F}$ & EPA & 0.31 & 3.5 \\
\hline Grain dust & $1987 \mathrm{~F}$ & OSHA-S & 4.00 & 6.7 \\
\hline Radionuclides/uranium mines & $1984 \mathrm{~F}$ & EPA & 1.10 & 8.7 \\
\hline Benzene & $1987 \mathrm{~F}$ & OSHA-H & 3.80 & 22 \\
\hline Arsenic/glass plant & $1986 \mathrm{~F}$ & EPA & 0.11 & 24 \\
\hline Ethylene oxide & $1984 \mathrm{~F}$ & OSHA.H & 2.80 & 32 \\
\hline Arsenic/copper smelter & $1986 \mathrm{~F}$ & EPA & 0.06 & 33 \\
\hline Uranium mill tailings, inactive & $1983 \mathrm{~F}$ & EPA & 2.10 & 35 \\
\hline Uranium mill tailings, active & $1983 \mathrm{~F}$ & EPA & 2.10 & 67 \\
\hline Asbestos & $1986 \mathrm{~F}$ & OSHA.H & 74.70 & 110 \\
\hline
\end{tabular}

(Continued on next page) 
Table 10. The Costs of Various Risk-Reducing Regulations per Life Saved (continued)

\begin{tabular}{|l|l|l|l|l||}
\hline \multicolumn{1}{|c|}{ Regulation } & \multicolumn{1}{|c|}{$\begin{array}{l}\text { Year } \\
\text { and } \\
\text { status }\end{array}$} & Agency & $\begin{array}{c}\text { Annual } \\
\text { lives } \\
\text { saved }\end{array}$ & $\begin{array}{c}\text { Cost per } \\
\text { life saved } \\
\text { (Millions } \\
\text { of 1990 } \\
\text { Dollars) }\end{array}$ \\
\hline Asbestos & $1989 \mathrm{~F}$ & EPA & 10.00 & 130 \\
\hline Arsenic/glass manufacturing & $1986 \mathrm{R}$ & EPA & 0.25 & 180 \\
\hline Benzene/storage & $1984 \mathrm{R}$ & EPA & 0.043 & 250 \\
\hline Radionuclides/DOE facilities & $1984 \mathrm{R}$ & EPA & 0.001 & 260 \\
\hline Radionuclides/elem. phosphorous & $1984 \mathrm{R}$ & EPA & 0.046 & 340 \\
\hline Benzene/ethylbenzenol styrene & $1984 \mathrm{R}$ & EPA & 0.006 & 610 \\
\hline \begin{tabular}{|} 
Arsenic/low-arsenic copper \\
Benzene/maleic anhydride
\end{tabular} & $1986 \mathrm{R}$ & EPA & 0.090 & 960 \\
\hline Land disposal & $1984 \mathrm{R}$ & EPA & 0.029 & 1,000 \\
\hline EDB & $1988 \mathrm{~F}$ & EPA & 2.520 & 4,400 \\
\hline Formaldehyde & $1987 \mathrm{~F}$ & OSHA-H & 0.002 & 20,000 \\
\hline
\end{tabular}

-Viscusi's 1992 data increased by a factor of 1.26 to account for inflation.

${ }^{b} \mathrm{~F}, \mathrm{P}$, or $\mathrm{R}=$ Final, proposed, or rejected rule.

Source: Viscusi (1992) after Morrall (1986). Status information was updated by John F. Morrall III via unpublished communication with Viscusi, July 10, 1990. 
Table 11. Costs of Life-Saving Actions in Occupational Safety

\begin{tabular}{|c|c|}
\hline Item & $\begin{array}{c}\text { Cost per Life Saved } \\
\text { (Millions of } 1990 \\
\text { Dollars) } \\
\end{array}$ \\
\hline Adding sulfur scrubbers in power plants ${ }^{\bullet}$ & 1.3 \\
\hline Civilian aircraft" & 3 \\
\hline Air force pilot safety & 5 \\
\hline Acrylonitrile $(2 \mathrm{ppm})^{\mathrm{b}}$ & 7.0 \\
\hline Coke ovens ${ }^{b}$ & 11 \\
\hline Arsenic $(0.004 \mathrm{mcl} \mathrm{rule})^{\mathrm{b}}$ & 12 \\
\hline Coal mine safety" & 55 \\
\hline Other muine safety" & 85 \\
\hline & $\begin{array}{c}\text { Mean } \approx 22 \\
\text { Median } \approx 9 \\
\text { Maximum }=85\end{array}$ \\
\hline
\end{tabular}

'Cohen (1980)

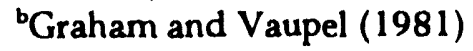

Table 12. Costs of Life-Saving Actions in Radiation-Related Activities

\begin{tabular}{||l|c|}
\hline \multicolumn{1}{|c|}{ Item } & $\begin{array}{c}\text { Cost per Life Saved } \\
\text { (Millions of 1990 Dollars) }\end{array}$ \\
\hline Medical x-ray equipment" & 0.009 \\
\hline Radon remediation in homes & \\
\hline Radium in drinking water & 0.7 (at 4 pCi/L) \\
\hline General radwaste practice & 6.1 \\
\hline Civilian high-level waste & 24 \\
\hline Defense high-level waste & \\
\hline & 44 \\
\hline & 490 \\
\hline
\end{tabular}

'Cohen (1980)

bUSEPA (1992) 
Approaches

For radon reduction, Schiager (1990) argued that even $\$ 200,000$ per life saved at an action level of 20 $\mathrm{pCi} / \mathrm{L}$ is too high, basing his argument on consideration of average life shortening due to the predicted lung cancers and the average personal income per year of $\$ 16,444$ (in 1988); this yields an average loss of income of $\$ 250,000$ per lung cancer. This approach is equivalent to a minimum humancapital approach to the evaluation of life saved, but neglects medical costs, pain and suffering, joy of living, and other factors that most individuals value highly. On the other hand, many individuals, given the choice, will not spend the \$200/y (Schaiger, 1990) estimated additional costs for heating and ventilation to remediate a typical home. Perhaps they sense that they have many more cost-effective choices in the areas of automobile safety, health care, and home safety. 


\section{Quantitative Methods in Dose Control}

\subsection{The Use of Cost-Benefit Analysis in Optimization of Radiation Protection}

The goal of the optimization process, as outlined by ICRP Publications 22, 26, 37, and 55 (1973, 1977. $1983,1989)$ is to maximize the net benefit of an operation. In this process, the changes in costs and benefits are considered that might be involved in requiring an activity to be performed at one level of dose, rather than another. The net benefit, B, can be considered in terms of gross benefit, $V$, less the sum of three general categories of cost: (1) the basic production cost, $P,(2)$ the cost of achieving a selected level of protection, $X$, and (3) the cost of detriment, $Y$. This can be expressed by the following equation:

$$
B=V-(P+X+Y)
$$

In the differential cost-benefit analysis, changes are evaluated in each of these costs relative to changes in collective dose, $\mathrm{S}$, resulting from the practice. The optimum net benefit then is obtained when equation 2 is satisfied:

$$
\frac{d V}{d S}-\left(\frac{d P}{d S}+\frac{d X}{d S}+\frac{d Y}{d S}\right)=0
$$

Generally, the gross benefit, V, can be considered constant. In this case, the differential of $\mathrm{V}$ is zero and the equation simplifies to:

$$
\frac{d X}{d S}=-\left(\frac{d P}{d S}+\frac{d Y}{d S}\right)
$$

Figure 1 shows these costs schematically and how they typically vary with collective dose. The net benefit is a maximum, and the point of optimization occurs at the collective dose where total costs are a minimum. At this point, the slope of the curve for radiation protection cost equals the negative slope of the (production + health detriment) curve, and the value of dose avoided is equal to $\alpha+\beta+\gamma$ (total $\$ /$ person - Sv), where $\alpha, \beta$, and $\gamma$ are coefficients for objective health detriment, other health and social detriments, and added costs of production, respectively, and may be expressed in monetary units. The coefficient $\gamma$ has not been specifically employed by the ICRP, but is used here to make clear the fact that costs of meeting dose limits are a major factor in the determination of value of dose avoided when individual doses approach limits.

In the more general case, both the costs of production and detriment may be a function of the distribution of dose among individuals. In this case, $Y$ and $P$ can be expressed as:

$$
Y=\alpha S+\sum_{j} \beta S_{i}
$$

$$
P=\sum_{j} \gamma_{i} S_{j}
$$

where $\beta_{1}$ and $\gamma_{1}$ are functions of individual doses. $\beta_{1}$ depends on risk aversion attitudes and national or managerial requirements; $\gamma$, depends on additional costs of production attributable to the individual doses; and $S_{1}$ is the collective dose to the individuals in the jth group. The term for $\mathrm{Y}$ is defined in ICRP Publication 42 (ICRP, 1984). The term for $P$ is defined here to reflect the corresponding increases in value of dose avoided due to increased costs of production attributable to individual dose distributions. This might include, for example, the cost of hiring additional workers to avoid exceeding dose limits. Note that this increased cost of production can be, and often is, included as part of the cost of radiation protection. As the dose to an individual or group of individuals approaches a dose limit, the associated risk approaches the unacceptable value, as defined by that limit, and forces those controlling exposures to spend more money to avoid these larger exposures. This is show $n$ schematically on Figure 2 where the costs of 


\section{Methods}

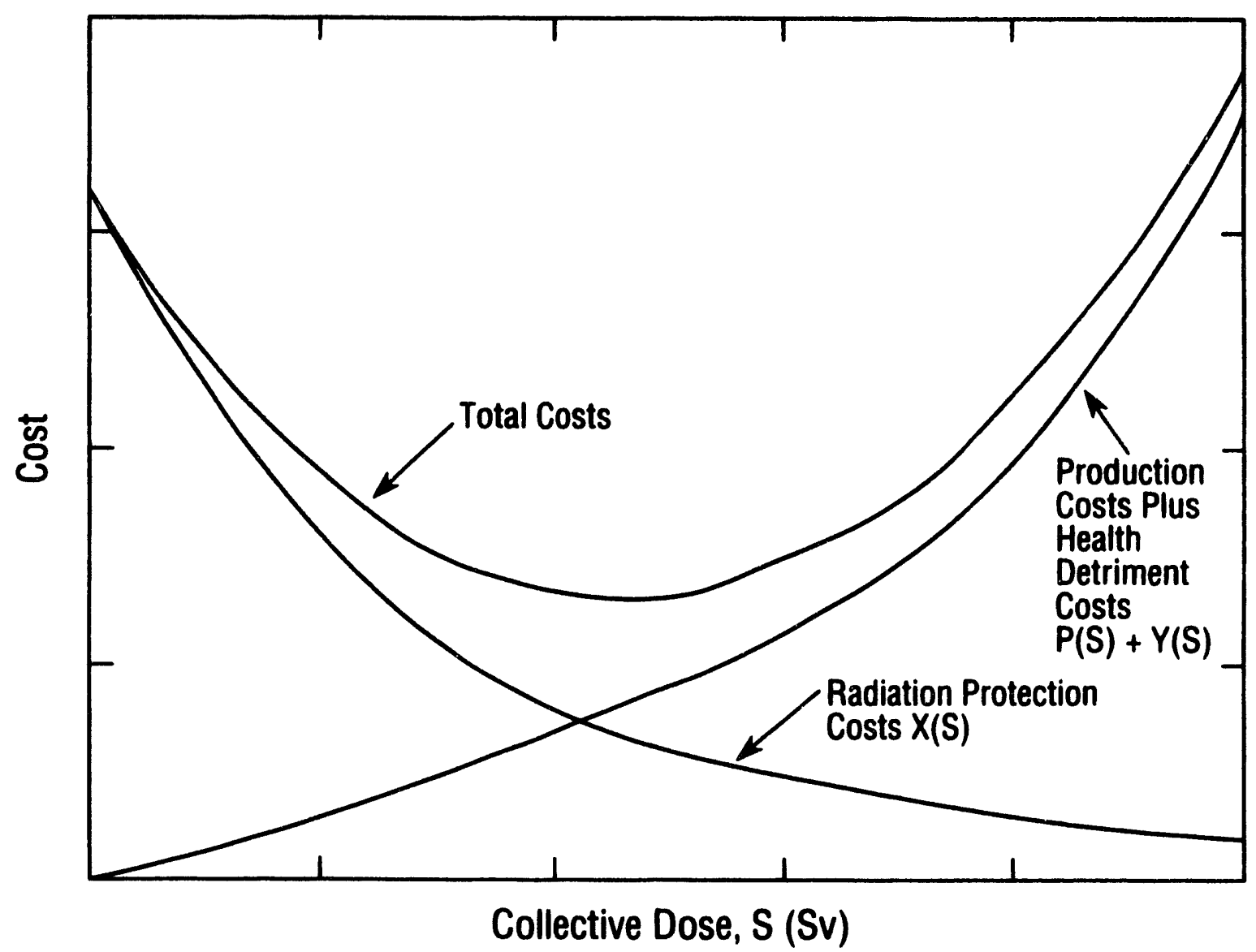

Figure I. Schematic of Costs vs. Collective Doses

production, radiation protection, and health detriment are plotted versus collective dose in J subgroups. These coefficients each have values of dollar per person $\mathrm{cSv}$ or dollars per person rem. The commonly quoted alpha term is generally considered a minimum or baseline value which is applicable at very low doses and is acknow-ledged to reflect only a part (loss of productivity and medical costs) of the health detriment costs.

Curve I shows variation of objective health detriment $(\alpha S)$ with collective dose in any subgroups. Curve 2 shows typical radiation protection costs $(\mathrm{X})$ vs. dose allowed in a group. Curve 3a shows possible variations of the cost of detriment to the public $\left(\alpha S+\beta S_{1}\right)_{p}$ vs. dose to subgroups. As critical dose limits (e.g., $1 \mathrm{msSv} / \mathrm{y}, 5$ $\mathrm{mSv} / \mathrm{y}$ or $50 \mathrm{mSv} / \mathrm{y}$ ) are reached, costs tend to increase sharply. The applicable limit may depend on circumstances, e.g., design stage to control routine exposures, or post-accident stage decisions on remediation. Curve $3 b$ shows typical cost variations for occupational workers $\left(\alpha S+\beta S_{1}\right)_{w}$. As the $50 \mathrm{mSv} / \mathrm{y}$ limit is approached, much greater costs are incurred to avoid exceeding the regulatory limit. Curve 4 shows that, in some cases, the cost of production $\left(\gamma S_{1}\right)$ also may increase markedly as individuals approach dose limits because of the costs incurred if a plant is shut down due to high doses or the need for additional planning and training to avoid them. 
Methods

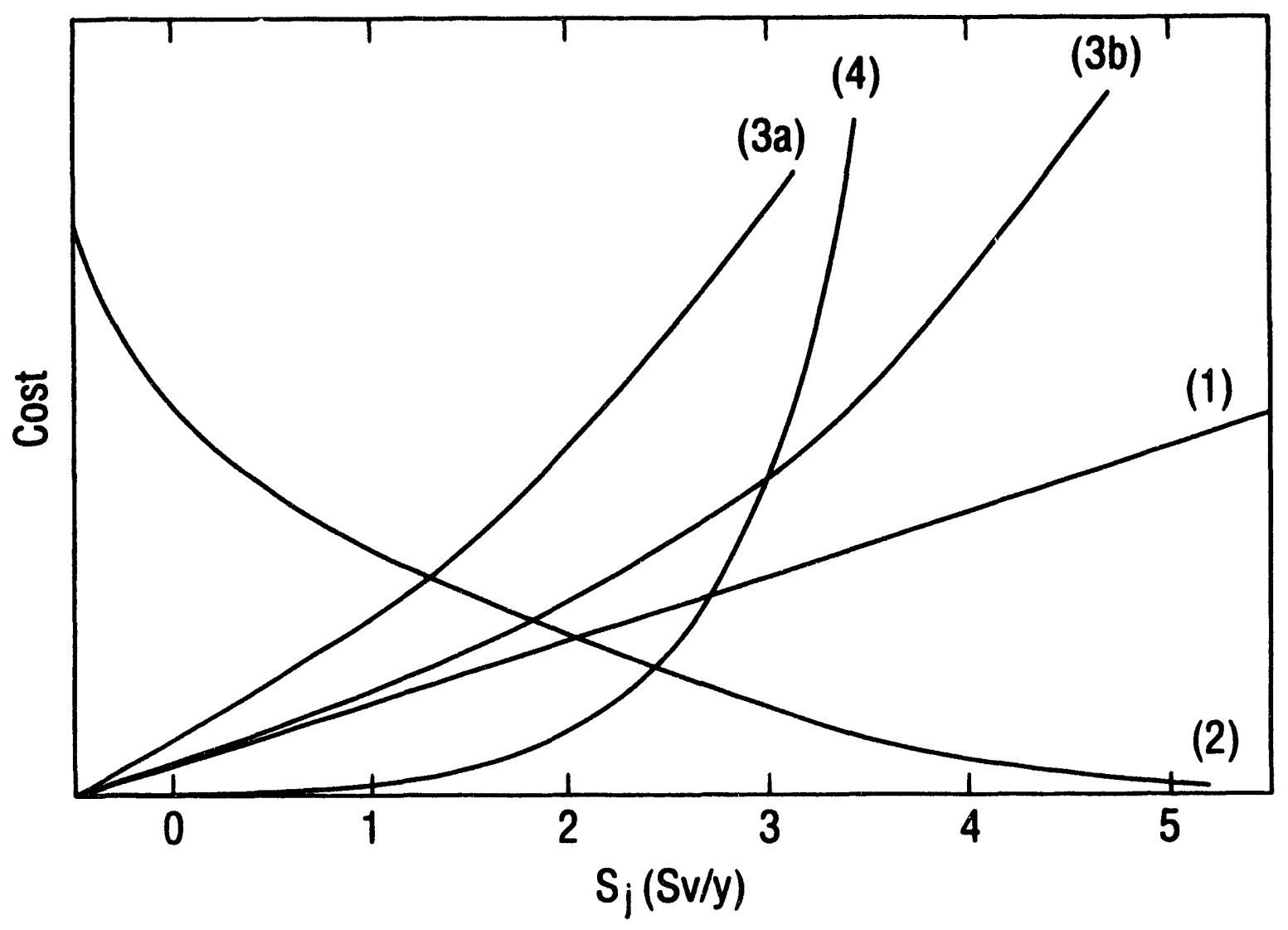

Figure 2. Schematic of Cost Variations vs. Individual Doses

The beta coefficient is a monetary value assigned by the decision maker to the added costs associated with non-objective features (such as pain and suffering or anxiety), and some of non-health detriments that might include, for example, the desire of society to avoid large variations in the distribution of collective dose which may place an unacceptable burden on any one individual. The gamma coefficient is important in arriving at the most cost-effective way to keep doses below the limits. As such, it is somewhat different than the coefficients used to achieve doses as low as reasonably achievable. It is especially important in nuclear power plant radiation exposure control. Risk factors associated with the principal health detriments were evaluated by the ICRP in its 1990 recommendations (ICRP, 1991). Nominal values for these risk factors are summarized in the table below. They include estimates for fatal cancer, nonfatal cancer, and severe hereditary effects for both adult workers and the whole population. The ICRP uses the term detriment to represent the combination of the probability of occurrence of a harmful effect and a judgment of the severity of the effect. If monetary values can be assigned for each statistical death from cancer, then an appropriate value for alpha, reflecting the total objective health detriment, can be deduced for each population using the total detriment values given here. Various factors were considered in arriving at an appropriate monetary value of dose avoided to be used to prevent fatalities or "statistical deaths" in various situations: these factors are summarized in the following sections. 
Methods

Nominal Probability Coefficients for Stochastic Effects"

\begin{tabular}{lcccc}
\hline & \multicolumn{4}{c}{ Detriment $\left(10^{-2} \mathrm{~Sv}^{-1}\right)^{\mathrm{b}}$} \\
\cline { 2 - 5 } $\begin{array}{c}\text { Exposed } \\
\text { Population }\end{array}$ & Fatal Cancer & $\begin{array}{c}\text { Non-Fatal } \\
\text { Cancer }\end{array}$ & $\begin{array}{c}\text { Severe } \\
\text { Hereditary } \\
\text { Effects }\end{array}$ & Total \\
\hline Adult workers & 4.0 & 0.8 & 0.8 & 5.6 \\
$\begin{array}{l}\text { Whole } \\
\text { population }\end{array}$ & 5.0 & 1.0 & 1.3 & 7.3 \\
\hline
\end{tabular}

-ICRP, 1991

${ }^{b}$ Rounded values.

'For fatal cancer, the detriment is equal to the probability coefficient.

\subsection{National Radiological Protection Board (U.K.) Recommendations}

The U.K National Radiological Protection Board has been developing guidance on cost-benefit analysis in radiation protection since the early 1980 s, considering both the human capital approach and the WTP rationale (NRPB, 1980, 1981, 1982, 1985, 1986, 1993a, 1993b, 1993c, 1993d, 1993e; Webb, 1984). Until recently, the Board resisted using values based on the WTP approach based on "the paucity of reliable WTP data." However, in their most recent recommendations (NRPB, 1993e), the Board cites recommendations of the Royal Society (1992) that suggested a value of life in the range $£ 2,000,000$ to $£ 3,000,000$ (about $\$ 3$ million $\$ 4.5$ million US), and a recent study by lves et al (1993) indicating a value of $£ 1,600,000$ (\$2.4 million, 1990 prices). These values were used to arrive at a value of life-year of $£ 30,000-£ 60,000$ $(\$ 45,000-\$ 90,000)$. For the U.K public, life lost from both somatic and hereditary effects is about one year per Sv (NRPB, 1993f). Risk values and years of life-lost per Sv for various groups then were calculated to reach a value of dose at the risk level of the WTP studies; this was about $£ 30,000-£ 60,000$ per person-Sv (about $\$ 450$ - $\$ 900$ per person-cSv) at an average annual dose of a few millisieverts (few hundred mrem). The upper value $£ 60,000$, was divided by six to arrive at a baseline value of $£ 10,000 /$ person-cSv. Finally, a multiplier was used to account for the individual's increasing aversion to increasing risks. The multiplier used by the U.K is shown on Figure 3. It begins at 1 for doses below about $10^{-7} \mathrm{~Sv} / \mathrm{y}\left(10^{-5} \mathrm{rem} / \mathrm{y}\right)$ and increases to about 13 at $0.1 \mathrm{~Sv} / \mathrm{y}$ (10 rem/y). The multiplier is shown as a fuzzy curve to indicate that the process is not precise and other factors need to be considered.

They further reasoned that for the low doses generally received by the public (a few 10s of $\mu \mathrm{Sv} / \mathrm{y}$ or a few mrem/y) the multiplier should be between oive and two. A value of two was finally chosen, giving a value of $\$ 300$ per person-cSv (Table 13). Table 13 also shows the earlier values recommended by the NRPB, and values recommended for specific groups. The earlier values were based on lower risk estimates (nearly a factor of four).

The consultative document (NRPB, 1980) also recommended that a discount rate of 0 to $3 \%$ be used for both costs and benefits (detriments avoided). More recent recommendations do not address this issue, leaving it up to the users of the recommendations to apply what they consider appropriate. 
Methods

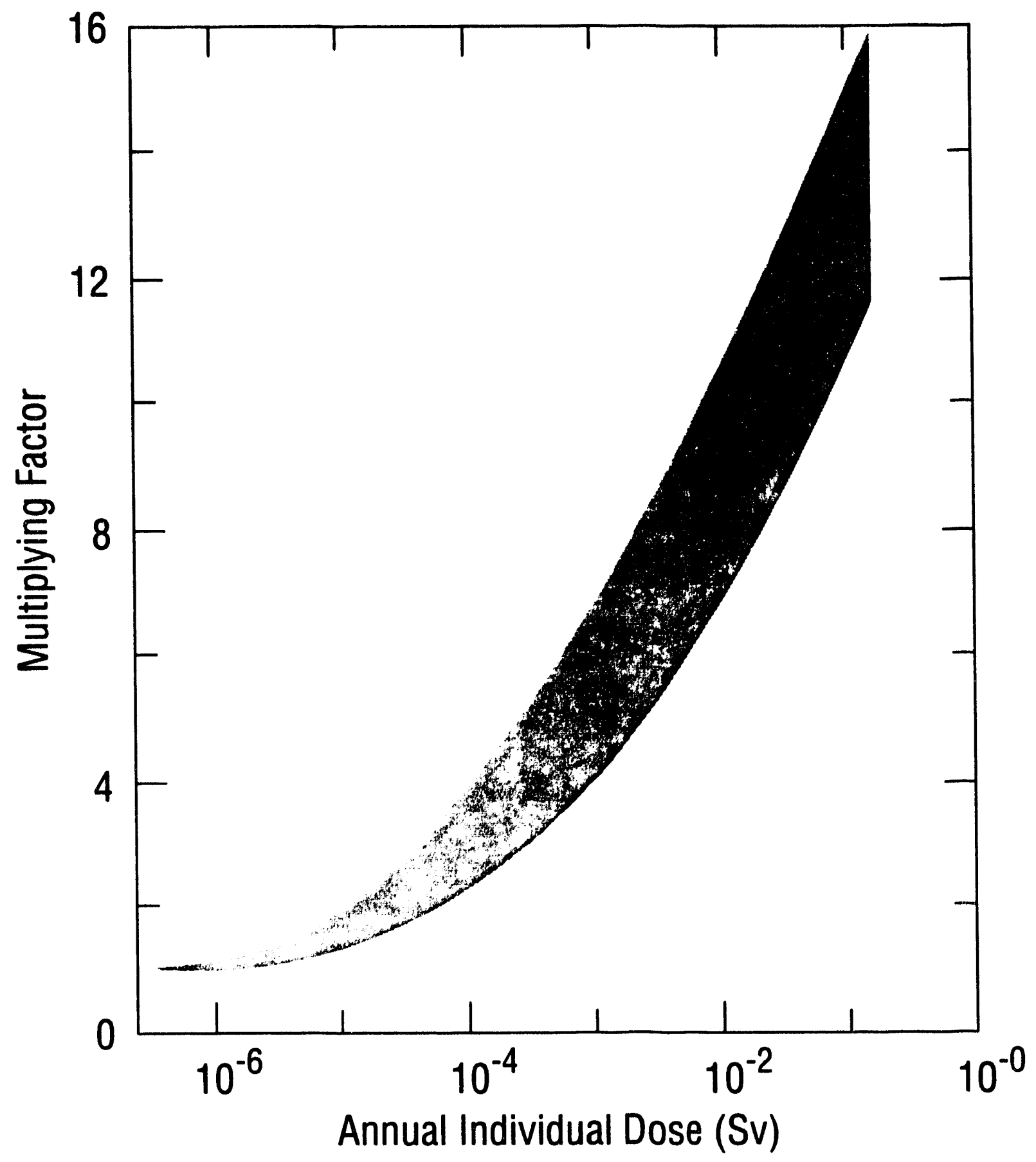

Figure 3. Multiplier used by NRPB to be applied to baseline detriment costs as a function of annual individual dose from the source (from NRPB 1993e with permission). 
Table 13. NRPB Recommendations

\begin{tabular}{|c|c|c|c|c|}
\hline & \multicolumn{4}{|c|}{ Equivalent 1990 US. Dollars Per Person - aSy } \\
\hline & $1980^{b}$ & $1986^{\mathrm{c}}$ & $1988^{d}$ & $1993^{e}$ \\
\hline Baseline & $\approx 70$ & 45 & 75 & 150 \\
\hline Geriatric patients & - & $\ldots$ & -. & 150 \\
\hline General public & $\approx 350$ & 75 & 150 & 300 \\
\hline General medical patients ${ }^{f}$ & - & -- &.- & 750 \\
\hline General Occupational & $\approx 700$ & 225 & 450 & 750 \\
\hline Occupational at $\approx 1 \mathrm{cSv} / \mathrm{y}$ & $-\cdot$ & - & -. & 1,200 \\
\hline Pediatric medical patients & .. &.- & 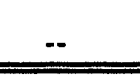 & 1,500 \\
\hline
\end{tabular}

"British pounds converted to dollar values of the time and then inflated to 1990 US equivalents in dollars.

bNRPB (1980). Values were expressed in three dose ranges for public and three higher ranges for occupational exposures. Values noted here are approximate equivalents.

'NRPB (1986), Robb (1990)

${ }^{d}$ Robb and Wrixon (1988), Robb (1990)

'NRPB (1993e). Values expressed in current dollars (not deflated to 1990 values).

'Other recommendations on medical exposures were between $£ 5,000$ and $£ 10,000$ per person-Sv for general diagnostic radiology (with a suggestion that this could be increased by a factor of 5 for pediatric exposure) (Russell and Webb, 1987); and an updated value of £12,500 per person-Sv in 1990 (NRPB, 1990).

\subsection{Valuation of Dose Avoided in France}

The implementation of ICRP recommendations to keep doses as low as reasonably achievable, with equitable dose distribution among individuals led Électricité de France (EDF) to adopt a system of reference monetary values for the unit of collective dose averted that varies from a base (or minimum) value $\alpha_{\text {Base }}$, which applies at doses $s d_{0}$. The value for $\alpha_{\text {Bac }}$ is determined from the French gross national product (GNP) and using the human capital approach. The reference value $\alpha_{\text {Ref }}$ then is related to the base value by a power function of dose, to the upper level of annual indiridual exposure. This is expressed as:

$$
\alpha_{\text {Ref }}=\alpha_{\text {Base }}\left(d / d_{o}\right)^{*}
$$

where $\mathrm{d}$ is the annual level of an individual dose. The exponent, a, reflects the degree of aversion that workers or society have to higher risks. Since 1992, EDF has employed a value of 1.35 for the exponent, a. EDF uses 100,000 French francs per person-Sv ( $\approx \$ 160$ per person-rem in 1990 values) for $\alpha_{\text {Base }}$ and applies $\alpha_{\text {Bare }}$ from zero to $1 \mathrm{mSv} / \mathrm{y}$ (100 
mrem/y). Table 14 shows the values employed between zero and $50 \mathrm{mSv} / \mathrm{y}$ ( 5 rem/y). Between 30 . $50 \mathrm{mSv} / \mathrm{y}$ ( 3 to $5 \mathrm{rem} / \mathrm{y}$, or just below the U.S. occupational dose limits), the EDF uses a value of $15,000,000$ F.f. $(\approx 24,000 /$ rem in 1990 values). These values are applicable at occupational doses large enough that factors such as dose limit concerns are important contributors to costs, and is reflected in Table 15 by the inclusion of $\beta$ and $\gamma$ in the third column. These high occupational values are not appropriate for setting values of dose avoided for the public. However, the lower value $\left(\alpha_{\text {Base }}\right)$ may, be since it is employed for doses in the range permitted for public exposure.

\subsection{Values of Dose Avoided in U.S. Nuclear Power Plants}

The values above can be compared to values employed in U.S. nuclear power plants in the early 1990s, summarized on Figure 4, which was compiled by G.W. Kindred (personal communication, 1992). The values range from about $\$ 2,500$ /person-cSv to $\$ 26,000$ /person-cSv, not too different from the EDF values. They are about an order of magnitude higher than values recommended by the UK NRPB, which does not exclude higher values. The Board suggests that "it is entirely reasonable for organizations to adopt monetary values of unit collective dose for internal use that are larger than those rec- ommended by the Board" (NRPB, 1993c). Some differences are due to the emphasis placed on dose reductions at U.S. facilities that were higher than in most developed countries during the early 1980s, shortly after the Three Mile Island nuclear incident (Baum and Horan, 1985). The large fraction of U.S. collective dose received by workers having doses near the limits caused many plants to evaluate dose avoided in terms of the costs of hiring replacement workers at a nominal cost of about $\$ 50,000$ (including fringe benefits and overhead costs) or $\$ 10,000$ per $\mathrm{CSv}$ of dose permitted. There have been significant reductions in collective doses (about a factor of two) during the past ten years. Therefore, logically. valuations of dose avoided are expected to be lower in the future, assuming that collective doses continue to be low. However, the ICRP recommendations (ICRP, 1991) to limit individual doses to 100 $\mathrm{mSv}$ per 5 -year period (average of 2 rem/y) and no more than $50 \mathrm{mSv}$ in any single year, and the introduction of the concept of dose constraints, and the NCRP recommendation (NCRP, 1987) to limit accumulated dose in $\mathrm{mSv}$ to less than ten times age (<age $x 1$ rem) will put additional pressure on operators to value the dose avoided at even higher values since these limits add an additional constraint to keep doses low.

Table 14. The EDF System for Occupational Exposures

\begin{tabular}{|c|c|}
\hline Annual Individual Level of Exposure & $\begin{array}{c}\text { Equivalent 1990 U.S. Dollar } \\
\text { Per Person-cSv }\end{array}$ \\
\hline $0.1 \mathrm{mSv}(0-100 \mathrm{mrem})$ & 160 \\
\hline $1-5 \mathrm{mSv}(100-500 \mathrm{mrem})$ & 800 \\
\hline $5.15 \mathrm{mSv}(500-1500) \mathrm{mrem})$ & 3,700 \\
\hline $15.30 \mathrm{mSv}(1500-3000 \mathrm{mrem})$ & 11,000 \\
\hline $30-50 \mathrm{mSv}(3000-5000 \mathrm{mrem})$ & 24,000 \\
\hline
\end{tabular}

'Reduced by $10 \%$ from 1992 values to adjust for inflation. 
Methods

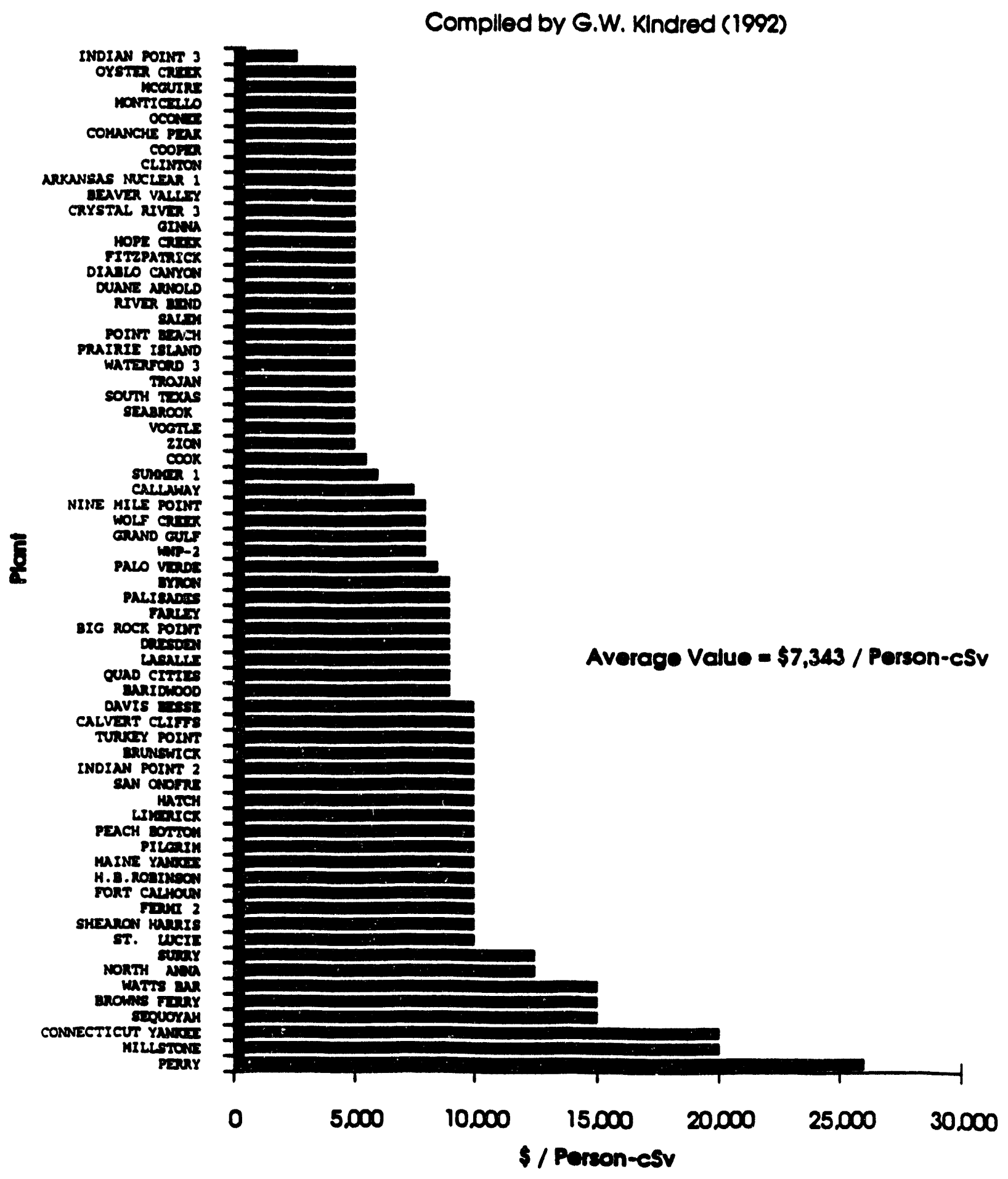

Figure 4. Values of dose avoided in U.S. nuclear power plants. 
These large values reflect operational costs ( $\gamma$ factor inthis report) and are not appropriate at the lower doses encountered in public exposures. Therefore, they are not included in the Table 1 summary.

\subsection{Value of Dose Avoided and Proposed Rules Under Consider- ation in Sweden}

The Swedish Radiation Protection Institute, which provides guidance for Denmark, Finland, Iceland, Norway, and Sweden, has reviewed the economic, protection, and ethical aspects of dose control in attempts to arrive at a reasonable cost for protection against radiation and other risks (Bengtsson and Moberg, 1993). They cite Swedish studies that indicate societies' willingness to pay for a year's postponement of death corresponded to about two times the average annual gross national product per person for road safety protection (Persson and Cedervall, 1991), 5-10 times the average annual gross national product based on a literature search by the Government Accounting Office (Mattsson, 1990). From these studies, the Institute proposed a three-tier system of rules for decision- making. To prevent a serious radiation injury, the protective measures are: (a) highly urgent if cost is $<\$ 1,000,000$ (U.S.), (b) urgent if cost is from $\$ 1,000,000$ to $\$ 5,000,000$ (U.S.), and (c) do not demand the protective measure if costs if $>\$ 5,000,000$ (U.S.) unless there are special reasons. Using the total risk probability coefficient for the whole population $\left(7.3 \times 10^{-2}\right.$ per $\left.\mathrm{Sv}\right)$ given on page 14 , these values are equivalent to expenditures of $<\$ 730$ per person-cSv, $\$ 730$ to $\$ 3,650$ per person$c S v$, and $>\$ 3,650$ per person-cSv, respectively.

The Swedish nuclear power plants operated by Vattenfall (Ringhals and Forsmark) employ a tentative value of $\alpha$ of 2 MSEK per person-Sv (\$2,500/person-cSv) as a value of occupational dose avoided at their plants (K Egner, personal communication, 1993). Other plants operated by the Sydkraft Company (Oskarshamn and Barseback) are considering various ways of setting $\alpha$ and $\beta$ values (B. Löwendahl, personal communication, 1993). One scheme is shown on Figure 5 that includes a baseline value at the equivalent of
$\$ 500,000 /$ person-Sv $(\$ 5,000 /$ person-rem) and multipliers of one to 2.4, which depend on both collective and individual doses. For collective doses of about 1 person-Sv ( 100 person-rem), the multiplier is one for individual doses less than $5 \mathrm{mSv}$ ( $<500 \mathrm{mrem}$ ), 1.2 for individual doses between 5.20 $\mathrm{mSv}(500 \cdot 2,000 \mathrm{mrem})$, and 1.5 for individual doses above $20 \mathrm{mSv}$ ( $2 \mathrm{rem}$ ). The multipliers increase linearly to values of $1.5,1.9$, and 2.4 , for collective doses of 7 person-Sv (700 person-rem). The muliplier for individual doses reflects the ICRP suggestion that attempts should be made to distribute doses uniformly when possible, whereas the multiplier for collective doses reflects the companies' and countries' goal to maintain reasonably low collective doses.

\subsection{Recommended Values of Dose Avoided in Various Countries}

Table 15 summarizes examples of information collected on values attributed to dose avoided in various countries. Values of $\alpha, \beta$, and $\gamma$ are shown as an indication of factors that have influenced the recommendation. Alpha refers, in general, to a minimum or baseline value to be used at the lowest doses and reflects primarily objective health detriments (lost wages and medical costs). Beta indicates that some consideration was given to dose distribution, and gamma indicates that values reflect other costs, such as hiring additional workers to avoid exceeding limits, or perhaps, increases in operational or cleanup costs that can be correlated with collective doses. That is, the total value of dose avoided can be, and often is, expressed with reference to dose, even if some of the benefits or avoided detriments are not health-related. This practice is common in valuing nuclear plant occupational dose avoided, even though it does not relate directly to health effects. The ICRP recommendations and examples have not included operational costs in the value of detriment ( $\alpha$ and $\beta$ ), yet for convenience in planning and calculations, this factor $(\gamma)$ is now commonly included in overall valuation of dose avoided. The $\gamma$ factor relates more to optimization of the practice since it is an operational cost incurred by dose limits as 
contrasted to costs of keeping doses as low as reasonably achievable (below the limits or dose constraints).

The lowest recommendation in Table 15 is that of the Health Physics Society Scientific and Public Issues Committee in their Position Statement: Radiation Dose Limits for the General Public (Kathren et al., 1993). This committee, which consists of four former presidents and the current President of the Health Physics Society, suggested that detriment should be measured in days of life lost or impaired, and this value used to estimate average loss of wealth or productivity based on per capita gross domestic product (GDP).

The Committee goes one step further, and considers that the U.S. population is currently spending $10 \%$ to $20 \%$ of GDP or $\$ 5-\$ 10$ per statistical day of life, on all forms of health, including programs of preventive health. Based on the average loss of 15 years of life per fatal cancer, a fatality risk of $5 \times 10^{4}$ per $\mathrm{cSv}$, and an additional $50 \%$ detriment due to non-fatal cancers and genetic effects (ICRP, 1991), the Committee calculates that the value of a person. cSv avoided is:

$$
\begin{aligned}
& \frac{\$ 10}{\text { day }} \times \frac{15 y}{\text { fatality }} \times 365 \frac{\text { day }}{y} \times 5 \times \\
& 10^{-4} \frac{\text { fatalities }}{c S v} \times 1.5=\$ 40 \text { per person-cSv }
\end{aligned}
$$

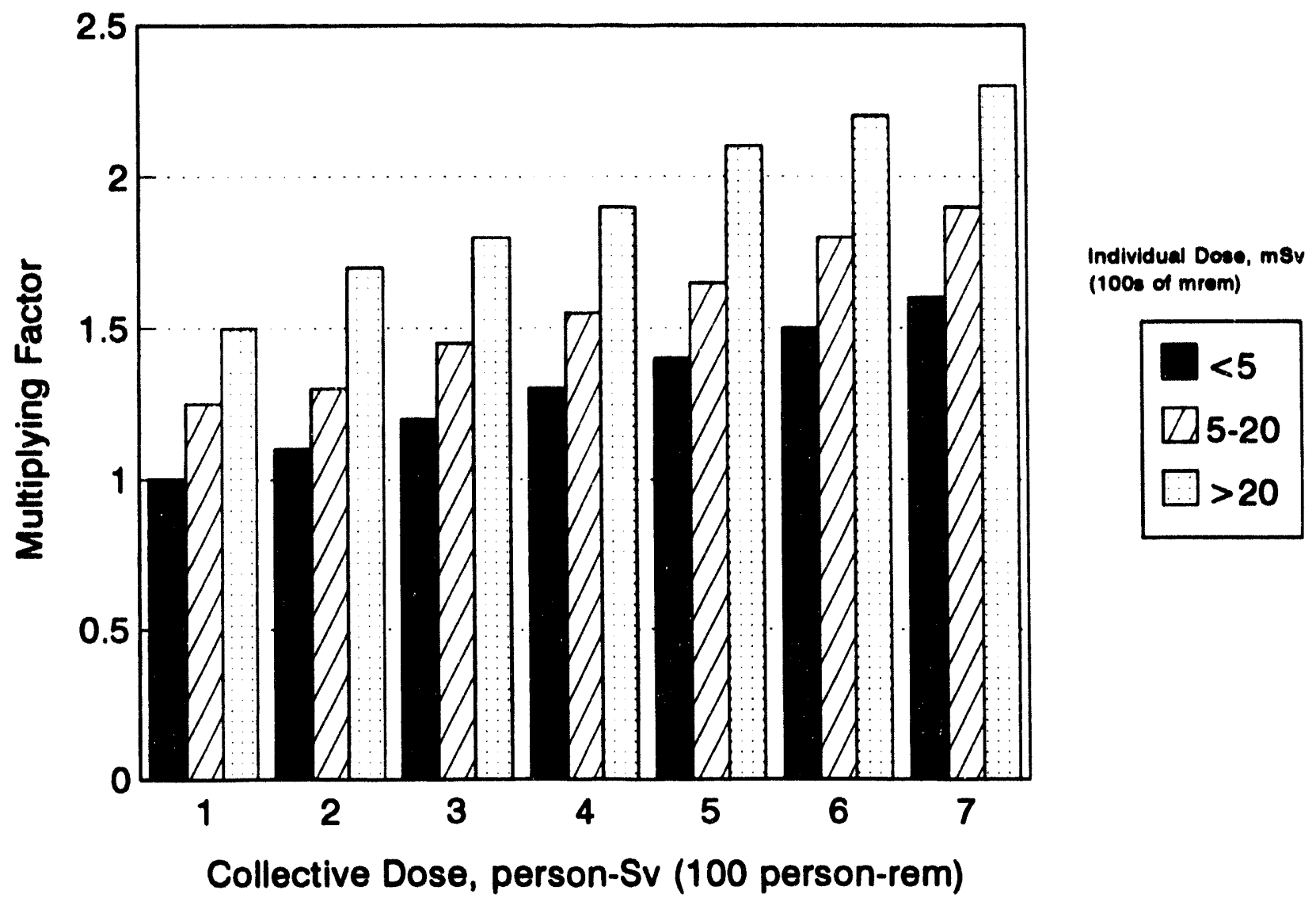

Figure 5. System of Dose Valuation being considered at Sydkraft

Company in Sweden (B. Löwendahl, personal communication, 1993). 
Table 15. Values of Dose Avoided Expressed in Equivalent 1990 U.S. Dollars

\begin{tabular}{|c|c|c|c|c|}
\hline Oroanization & Reference & Ouantity & Apolication & Dollars/Person-cSy \\
\hline Argentina & $\begin{array}{l}\text { Beninson and } \\
\text { Gonzalez (1981) }\end{array}$ & $\alpha$ & Public & 140 \\
\hline $\begin{array}{l}\text { CSFR } \\
\text { Czechoslovakia } \\
\end{array}$ & Hanusik, $V^{d}$ & $\alpha$ & $?$ & 90 \\
\hline $\begin{array}{l}\text { Nordic authorities } \\
\text { (Denmark, } \\
\text { Finland, Iceland, } \\
\text { Norway, and } \\
\text { Sweden) }\end{array}$ & $\begin{array}{l}\text { Bengtsson and } \\
\text { Högberg (1988) }\end{array}$ & $\alpha$ & $\begin{array}{l}\text { Public (food } \\
\text { contaminated by } \\
\text { Chernobyl) }\end{array}$ & $240^{\circ}$ \\
\hline $\begin{array}{l}\text { Nordic authorities } \\
\text { (Denmark, } \\
\text { Finland, Iceland, } \\
\text { Norway, and } \\
\text { Sweden) } \\
\end{array}$ & $\begin{array}{l}\text { Swedish Rad. } \\
\text { Prot. Inst. } \\
\text { (1991) }\end{array}$ & $\alpha$ & $?$ & $<1,000$ \\
\hline \multirow{3}{*}{$\begin{array}{l}\text { Swedish Radiation } \\
\text { Protection } \\
\text { Institute }\end{array}$} & \multirow[t]{3}{*}{$\begin{array}{l}\text { Bengtsson and } \\
\text { Moberg (1993) }\end{array}$} & $\alpha+\beta$ & $\begin{array}{l}\text { Action highly } \\
\text { urgent }\end{array}$ & $<750$ \\
\hline & & $\alpha+\beta$ & Action urgent & $750 \cdot 3,650$ \\
\hline & & $\alpha+\beta$ & $\begin{array}{l}\text { Action only for } \\
\text { special reason }\end{array}$ & $>3,650$ \\
\hline \multirow[t]{2}{*}{ EDF - France } & \multirow{2}{*}{$\begin{array}{l}\text { LeFaure et al } \\
\text { (1993) }\end{array}$} & $\alpha_{0}$ & Occupational & 160 \\
\hline & & $\alpha_{0}+\beta+\gamma$ & Occupational & 24,000 \\
\hline IAEA & IAEA (1985) & $\alpha_{\min }$ & $\begin{array}{l}\text { Public } \\
\text { (transboundary) }\end{array}$ & $40^{b}$ \\
\hline Italy & $\begin{array}{l}\text { Trenta, G.N. } \\
(1993)^{d}\end{array}$ & $\alpha+\beta$ & $\begin{array}{l}\text { Chernobyl } \\
\text { remediation } \\
\text { costs }\end{array}$ & $\sim 1,500$ \\
\hline \multirow[t]{4}{*}{ NRPB - U.K. } & \multirow[t]{4}{*}{ NRPB (1993e) } & $\alpha_{0}$ & $\begin{array}{l}\text { Baseline } \\
\text { public or worker }\end{array}$ & 150 \\
\hline & & $\alpha+\beta$ & General public & 300 \\
\hline & & $\alpha+\beta$ & $\begin{array}{l}\text { General } \\
\text { occupational }\end{array}$ & 750 \\
\hline & & $\alpha+\beta$ & $\begin{array}{l}\approx 1 \mathrm{cSv} / \mathrm{y} \\
\text { Occupational }\end{array}$ & $\approx 1,200$ \\
\hline
\end{tabular}

(Continued on next page) 


\section{Methods}

Table 15. Values of Dose Avoided Expressed in Equivalent 1990 U.S. Dollars (continued)

\begin{tabular}{|c|c|c|c|c|}
\hline Organization & Reference & Ouantity & Application & Dollars/Person-cSy \\
\hline \multirow{3}{*}{$\begin{array}{l}\text { Ontario Hydro } \\
\text { (Canada) }\end{array}$} & \multirow{3}{*}{$\begin{array}{l}\text { Ramsay and } \\
\text { Khan (1992) }\end{array}$} & $\alpha$ & Occupational & $\approx 130$ \\
\hline & & $\alpha$ & Public & $\approx 130$ \\
\hline & & $\alpha+\beta$ & Occupational & $\approx 1,000$ \\
\hline \multirow{2}{*}{$\begin{array}{l}\text { Swedish Sydkraft } \\
\text { Company } \\
\text { (Nuclear Power) }^{c}\end{array}$} & \multirow{2}{*}{$\begin{array}{l}\text { Lowendahl } \\
(1993)^{d}\end{array}$} & $\alpha$ & Occupational & 5,000 \\
\hline & & $\alpha+\beta$ & Occupational & 12,000 \\
\hline $\begin{array}{l}\text { Swedish Vattenfall } \\
\text { Co. (Nuclear } \\
\text { Power) } \\
\end{array}$ & $\begin{array}{l}\text { Egner, K. } \\
(1993)^{d}\end{array}$ & $\alpha+\beta$ & Occupational & 2,500 \\
\hline \multirow{2}{*}{$\begin{array}{l}\text { U.K. Atomic } \\
\text { Energy Authority }\end{array}$} & \multirow[t]{2}{*}{ UKAEA (1987) } & $\alpha$ & Occupational & $\leq 100$ \\
\hline & & $\alpha+\beta$ & Occupational & $\approx 100 \cdot 1,000$ \\
\hline USEPA & Page (1993) & $\alpha+\beta$ & $\begin{array}{l}\text { Public (Radon } \\
\text { Remediation) } \\
\end{array}$ & $<510$ \\
\hline \multirow[t]{2}{*}{ USHPS } & \multirow[t]{2}{*}{$\begin{array}{l}\text { Kathren et al. } \\
\text { (1993) }\end{array}$} & $\alpha$ & $\begin{array}{l}\text { Public } \\
<1 \text { person-cSv/y }\end{array}$ & $\approx 40$ \\
\hline & & $\alpha+\beta$ & $\begin{array}{l}\text { Public Near } \\
\text { Limits }\end{array}$ & $\approx 400$ \\
\hline USNRC & USNRC (1975) & $\alpha+\beta+\gamma$ & $\begin{array}{l}\text { Public and } \\
\text { Property } \\
\text { Damage } \\
\end{array}$ & 2,400 \\
\hline USNRC & USNRC (1993) & $\alpha+\beta$ & Public & 1,000 \\
\hline $\begin{array}{l}\text { U.S. Nuclear } \\
\text { Power Plants }\end{array}$ & $\begin{array}{l}\text { Kindred, G.W. } \\
(1992)^{d}\end{array}$ & $\alpha+\beta+\gamma$ & Occupational & $\begin{array}{l}2,000 \cdot 26,000 \\
\text { (Mean for U.S. } \\
\text { plants } 7,300 \text { ) }\end{array}$ \\
\hline
\end{tabular}

'Dairies actually destroyed milk at a cost of more than ten times this value (Bengtsson, 1988).

'Increased by a factor 1.36 to account for inflation since 1983 .

'Under consideration in 1993.

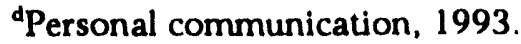

'Values in use or proposed after 1990 are in current values (not deflated to 1990) except those for EDF which were reduced by $10 \%$ from the published 1992 values. 
The Committee recommends that "...for avoiding small individual radiation doses (i.e., less than $1 \mathrm{rem}$ per year), distributed randomly throughout society, the appropriate expenditure is a few tens of dollars per personi-rem avoided." The statement seems to imply that even an individual dose of 1 rem per year to the public is small. Since this contradicts the Committee's next statement (below), it seems that the small dose should have been expressed as a collective dose of 1 person-rem distributed over a large number of people. This interpretation follows from their next recommendation: "...For doses near the individual dose limits recommended by the ICRP and NCRP in clearly identified populations, the appropriate expenditures may be as much as a few hundred dollars per person-rem avoided." The $\$ 40 /$ person-cSv value is about a factor of four below the NRPB baseline value of $\$ 150$ /person-cSv. The several hundred dollar (say, $\$ 400$ ) value near the dose limit is about one-half the value obtained from the NRPB multiplier curve ai $0.1 \mathrm{cSv} / \mathrm{y}$ (multiplier about five) and the U.K. baseline value of $\$ 150 /$ person-cSv $(5 \times \$ 150=\$ 750)$.

The $\$ 400$ value is very nearly the same as the value suggested by the EPA for radon remediation $(<\$ 510$ per person-cSv). However, the expected effective dose rate at the $4 \mathrm{pCi} / \mathrm{L}$ remediation action level is 1 to $2 \mathrm{cSv} / \mathrm{y}$ per person based on average concentrations of about $9 \mathrm{pCi} / \mathrm{L}$ for homes above that action level (Cohen, 1991). These dose rates are well above the public dose limits and would justify expenditures to four times higher than the EPA recommendation if the NRPB multiplying factor based on annual individual dose were employed (Figure 3).

The U.K Atomic Energy Authority, in its guidance to the nuclear industry, suggests a minimum value for occupational exposures that is equivalent to $\leq \$ 100$ /person-cSv at low doses; increasing to $\approx \$ 1,000 /$ person-cSv when other factors such as high individual doses, and collective dose trends are considered $d^{b}$. They suggest actions are possibly too expensive above this value, and that actions should probably be taken for choices below the lower value.

\footnotetext{
brank Phillips, personal communication, 1994.
}

Between these values, they suggest other factors are important, as illustrated on Figure 6.

The former Czechoslovakia employed a value of \$90/person-cSv based on GDP (Melichar and Vladar, 1992; Havlik, 1992).

Italian expenditures for remediating the food chain after the Chernobyl accident were about $\$ 1,500 /$ person-cSv ${ }^{d}$. For decision making in optimization assessments, Argentina has had a recommendation in effect since the early 1980 s that is equivalent to $\$ 140$ /person-cSv (Beninson and Gonzalez, 1981). By contrast, Poland', Germany', and Spain ${ }^{\ell}$ have no official recommended values.

The Nuclear Regulatory Commission in 1975 recommended \$1,000/person-cSv (\$2,400/personcSv in 1990 dollars) related to public exposures to effluents from nuclear power plants (USNRC, 1975). In 1985 the NRC staff ${ }^{\mathrm{h}}$ recommended that the $\$ 1,000$ value was sufficiently large that it could serve as a surrogate for both health effects and offsite property damage. The 1975 recommendation was based on earlier risk per unit dose coefficients. The dollar value per person-cSv is currently under reassessment by the NRC, which recommended $\$ 1,000$ /person-cSv as an interim value in its guidance on ALARA Levels for Effluents from Materials Facilities (USNRC, 1993).

V. Hanusik, personal communication, 1993.

drento, G.N., personal communication, 1993.

'Waligoraki, M.P.R., personal communication, 1993.

'Pfeffer, W., personal communication, 1993.

Carmena, personal communication, 1993.

hunpublished memorandum, W.J. Dircks to Commistion, "Basis for Quantifying Off-Site Property Losses," October 23, 1985. 
The 1975 NRC requirements also specified a value of $\$ 1,000$ per man-thyroid-rem to be used on an interim basis. The 1993 guidance (USNRC, 1993) employs the concept of total effective dose equivalent with weighting factor for various organs (USNRC, 1991). This is similar to the concept of effective dose, as employed by the ICRP (ICRP, 1991), although somewhat different weighting factors are employed. Using these weighting factors and expressing dose in Sv and person-Sv (rem and person-rem) avoids the need for separate monetary values to reflect value of dose avoided for specific organs.

Other values listed in Table 15 include a 1991 recommendation by the Nordic radiation protection authorities, which provide guidance for Denmark, Finland, Iceland, Norway, and Sweden. The authorities recommended that values should be less than $\$ 1,000$ /person-cSv. During remediation of contaminated food supplies after Chernobyl, the Nordic countries recommended food be interdicted if costs were $<\$ 240 /$ person-cSv. However, Bengtsson and Moberg (1988) reported that dairies destroyed milk at a cost ten times higher due to the considerable public attention and concern.
The International Atomic Energy Agency considered the costs that seem appropriate for limiting transboundary effluents (LAEA, 1985). The Agency recommended that authorities use a value, for objective health detriment for exposures outside their country, that is equal to or higher than the value used for exposures within their country provided that such value is equal to or higher than $\$ 30$ /person-cSv in 1983 prices (about \$40/personcSv in 1990 prices).

The Canadian utility, Ontario Hydro, after employing \$10,000/person-cSv in the early 1970 s when plant doses were relatively high (Baum and Horan, 1985), more recently has been using a minimum value of $\approx \$ 130$ /person-cSv for both public and occupational doses, with higher values to $\$ 1,000 /$ person-cSv for general occupational exposures (Ramsay and Khan, 1992). 


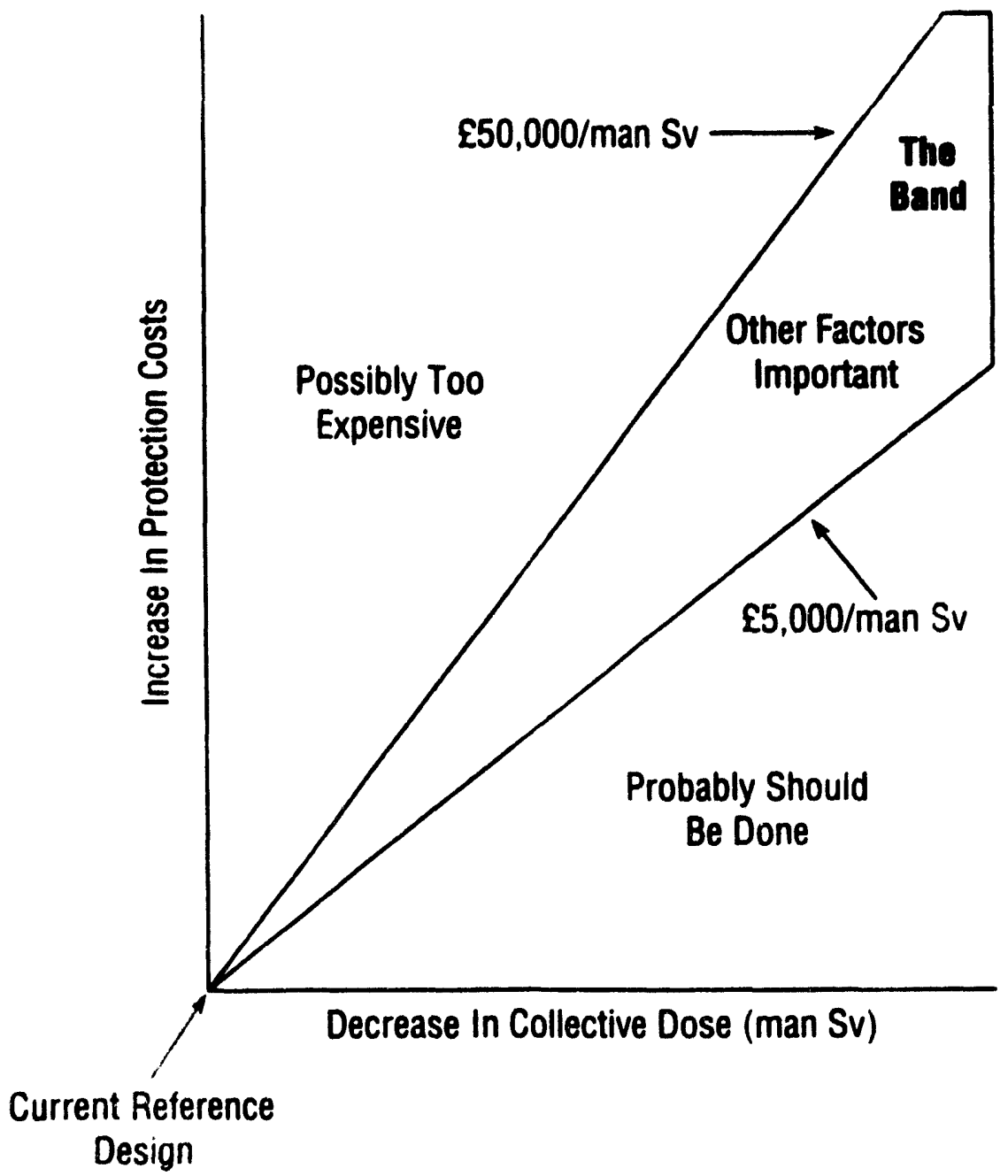

Figure 6. The "Band Scheme" used by UKAEA (after Croft and Lochard, 1988); currently employed monetary values provided by Frank Phillips, personal communication (1994). 


\section{Discussion}

The results of studies on health care actions (Table 2), transportation safety (Table 3 ), consumer product safety (Table 4), government agency values (Table 5), wage/risk compensation (Table 6), consumer behavior (Table 7), and WTP surveys (Table 9) are considered to be the best basis for judging society's willingness to pay for risk reduction. They yield values of $\$ 1,400,000$ to $\$ 2,700,0001990$ dollars per life saved, a surprisingly narrow range. From such information, various U.S. government agencies have used a value of about $\$ 1,700,000$, based partly on guidance from the Office of Management and Budget. 'This suggests that U.S. health and safety policy is directed toward use of the WTP approach, to valuing risk avoidance, rather than the older humancapital approach.

A similar trend is apparent in the evolution of guidance and regulations of agencies in the U.K and France. Their recommendations for exposures at 0.1 cSv/y are accepted as representative of society's nominal level of risk acceptance $\left(-10^{-4}\right.$ fatalities/y), and the risk range to be used for application of the above WTP values.

Using the latest ICRP risk coefficients (ICRP, 1991) of $4 \times 10^{-4}$ per $\mathrm{CSv}$ for fatal cancers for adults and $5 \times$ $10^{-4}$ for the whole population, the values of dose avoided can be calculated using a mean value for avoided fatality of $\$ 2,100,000$ :

For adults:

$$
4 \times 10^{-4} \times \$ 2.1 \times 10^{6} \approx \$ 840 / \text { person-cSv }
$$

For general populations:

$$
5 \times 10^{-4} \times 2.1 \times 10^{6} \approx \$ 1,000 / \text { person-cSv }
$$

These values could logically be increased by $40 \%$ and $46 \%$, respectively, to account for non-fatal cancers and genetic effects, i.e., total detriment as given on page 24, (ICRP, 1991) giving:

Value of dose avoided for adults $=$ $\$ 1,200$ /person-cSv
Value of dose avoided for the general public $=\$ 1,500 /$ person-cSv

Considering that radiation fatalities, on average, occur late in life and reduce lifespan by 15 years per cancer, whereas many accidents are immediately fatal and reduce lifespan by an average of about 30 years, it could be reasoned that the radiation-related values for $\alpha$ should all be lowered about a factor of two. In light of the uncertainties in its derivation, a nominal value of $\$ 1,000$ per person-cSv seems appropriate for public dose-avoidance decisions in the region below $0.1 \mathrm{cSv} / \mathrm{y}$ (the public limit).

Further study is needed to better judge the appropriate weighting factors to be used at very low doses, but a sliding scale down to about $\$ 280$ /person-cSv can be justified based on lost output and medical costs, or perhaps twice this figure if an equal amount is arbitrarily included for pain and suffering (Mubayi et al., 1992).

The value of $\$ 1,000 /$ person-cSv can be compared to the British value of $\$ 150$ (baseline) $\times 4$ (multiplying factor at $10^{-3} \mathrm{~Sv} / \mathrm{y}$ ) $=\$ 600$ /person-cSv at $0.1 \mathrm{cSv} / \mathrm{y}$. Assuming willingness to pay is proportional to per capita income, the U.S. value could be about $65 \%$ higher than the British value or $\approx \$ 1,000$. Lower values below this would be consistent with the ICRP Report 22 (ICRP, 1973) suggestion that in the region of individual dose near the limit, "...the monetary equivalent of man-rem could increase perhaps by a factor of 10 or so."

As a final thought on crude estimates of willingness to pay, we might ask if the U.S. society is willing to pay an additional $1 \%(\$ 5.5$ billion in 1991) in income taxes to avert about 2,600 fatal cancers per year. This is the approximate number expected for the general population $\left(\$ 5.5 \times 10^{9} \div \$ 2.1 \times 10^{6}\right.$ per fatal cancer averted.) The answer to this may well be that other options for safety would be preferred, in which case the value should be lower. However, this review suggests that this value is not inconsistent with many other expenditures for health and safety in the United States. 


\section{References}

Acton, J.P., Evaluating Public Proprams to Save Lives: The Case of Heart Attacks, Santa Monica: Rand Corporation, 1973.

Arnould, RJ. and L.M. Nichols, "Wage-Risk Premiums and Worker's Compensation: $A$ Refinement of Estimates of Compensating Wage Differentials," Lournal of Political Economy 91(2), 1983, pp. 332-340.

Baum, J.W., "ALARA at Nuclear Power Plants," BNL-NUREG-44508, Proceedings of the 24th Midyear Topical Meeting of the Health Physics Society, January 21-24, 1991, Raleigh, North Carolina, 199 la, pp. 165-180.

Baum, J.W., "Valuation of Dose Avoided at U.S. Nuclear Power Plants," Nuclear Plant Journal, March-April 1991, 1991 b. pp. 40-46.

Baum, J.W. and J.R. Horan, "Summary of Comparative Assessment of U.S. and Foreign Nuclear Power Plant Dose Experience," NUREG/CR4381, BNL-NUREG-51918, October 1985.

Bengtsson, G. and L. Högberg, "Status of Achievements Reached in Applying Optimisation of Protection in Prevention and Mitigation of Accidents in Nuclear Facilities," Proceedings of an ad hoc meeting on The Application of Optimisation of Protection in Regulation and Operational Practices, The OECD Nuclear Energy Agency, Paris, France, March 16-18, 1988.

Beninson, D. and A.J. Gonzalez, "Optimization of Nuclear Safety Systems," Proceedings of an International Conference on Current Nuclear Power Plant Safety Issues, held in Stockholm, Sweden, October 1980, LAEA-CN-39/211, Vol. 2, Vienna, Austria, 1981, pp. 449-455.

Beninson, D. and A.J. Gonzalez, "Application of the Dose Limitation System to the Control of Carbon14 Releases from Heavy-Water-Moderated Reactors." The Dose Limitation System in the
Nuclear Fuel Cycle and in Radiation Protection (Proc. Symp. Madrid, 1981), LAEA, Vienna, 1982.

Bengtsson, G. and L. Moberg, "What is Reasonable Cost for Protection Against Radiation and Other Risks?" Health Physics, Volume 64, Number 6, June 1993.

Bequele, A., "The Costs and Benefits of Protecting and Saving Lives at Work: Some Issues," International Labour Review, Vol. 123, No. 1, January-February 1984.

Blomquist, G., "Value of Life Saving: Implications of Consumption Activity," Lournal of Political Economy 87(3), 1979, pp. 540-558.

Blomquist, G. and T.R. Miller, "Values of Life and Time Implied by Use of Protection Equipment," The Urban Institute Working Paper 3525-06, 1990.

Brown, C., "Equalizing Differences in the Labor Market," Quarterly Journal of Economics 94(1), 1980, pp. 113-134.

Butler, RJ., "Wage and Injury Rate Responses to Shifting Levels of Workers' Compensation," in John D. Worrall (ed.), Safety and the Work Force, ILR Press, Cornell University, Ithaca (NY), 1983.

Cohen, B.L., "Society's Valuation of Life Saving in Radiation Protection and Other Contexts, " Health Physics, 38, 1980, pp. 33-51.

Cohen, B.L., "Radon in Homes: Is EPA OverReacting?" Health Physics Newsletter, January 1991.

Cousineau, J.M., R Lacroix, and A.M. Girard, "Occupational Hazard and Wage Compensating Differentials," Centre de Recheche et Development Economique, University de Montreal, 1988.

Croft, J.R and J. Lochard, "Status of Achievements Reached in Applying Optimization of Protection in Design and Normal Operation of Nuclear Facilities," 
Optimisation of Radiation Protection, Nuclear Energy Agency, March 1988, pp. 113-129.

Dickens, W.T., "Differences Between Risk Premiums in Union and Nonunion Wages and the Case for Occupational Safety Regulations," American Economic Review 74(2), 1984, pp. 320-323.

Dillingham, A., "The Influence of Risk Variable Definition on Value of Life Estimates," Economic Inquiry 24, 1985, pp. 277-294.

Dillingham, A. and T.R. Miller, "Effects of Nonfatal Risks on Value of Life Estimates," unpublished, Working Paper, The Urban Institute, 1990, cited by Miller (1990).

Dillingham, A. and R.S. Smith, " Union Effects on the Valuation of Life," Proceedings of the Industrial Relations Research Association Annual Meeting 36, 1984, cited by Miller (1990) .

Dorsey, S. and N. Walzer, "Workers' Compensation Job Hazards, and Wages," Industrial and Labor Relations Review 36(4), 1983, pp. 643-654.

DOT (1992). The Tolerability of Risk from Nuclear Power Stations, Revised, HSE Information Centre, Sheffield, U.K. 1992.

Fisher, A., L.G. Chestnut, and D.M. Violette, "The Value of Reducing Risks of Death: A Note on New Evidence," Lournal of Policy Analysis and Management, 8 (1), 1989, pp. 88-100.

Garen, J., "Compensating Wage Differentials and the Endogeneity of Job Riskiness," The Review of Economics and Statistics 70(1), 1988, pp. 9-16.

Gegax, D., S. Gerking, and W. Schultze, "Perceived Risk and the Marginal Value of Safety," unpublished manuscript, University of Wyoming, Laramie, 1987.

Gerking, S., M. de Haan, and W. Schulze, "The Marginal Value of Job Safety: A Contingent Valuation Study," Lournal of Risk and Uncertainty 1(2), 1988, pp. 185-199.
Ghosh, D., D. Lees, and W. Seal, "Optimal Motorway Speed and Some Valuations of Time and Life," Manchester School of Economic and Social Studies 43 (June), 1975, pp. 134-143.

Graham, J.D. and J.W. Vaupel, "The Value of Life: What Difference Does It Make?" Risk Analysis, No 1, 1, 1981, pp. 89-95.

Graham, J.D. and J.W. Vaupel, "The Value of Life: What Difference Does It Make?" in R Zeckhauser and Leebaert (eds.), What role for Government, Duke Press Policy Studies, 1983, pp. 176-186.

Herzog, H.W., Jr. and Schlottman, A.M., "Valuing Risk in the Workplace: Market Price, Willingness to Pay, and the Optimal Provision of Safety," unpublished, University of Tennessee Working Paper, 1987

IAEA (1985), "Assigning a Value to Transboundary Radiation Exposure," Safety Series No. 67.

ICRP (1973). International Commission on Radiological Protection. Implication of Commission Recommendations that Doses be Kept as Low As Readily Achievable, ICRP Publication 22, Pergamon Press, Elmsford, New York.

ICRP (1977). International Commission on Radiological Protection. Recommendations of the International Commission on Radiological Protection, ICRP Publication 26, Annals of the ICRP 1 (3), Pergamon Press, Elmsford, New York.

ICRP (1983). International Commission on Radiological Protection. Cost-Benefit Analysis in the Optimization of Radiation Protection, ICRP Publication 37, Annals of the ICRP $10(2 / 3)$. Pergamon Press, Elmsford, New York.

ICRP (1984). International Commission on Radiological Protection. A Compilation of the Major Concepts and Quantities in Use by ICRP. ICRP Publication 42, Annals of the ICRP 14 (4), Pergamon Press, Elmsford, New York. 
ICRP (1989). International Commission on Radiological Protection. Optimization and Decision-Making in Radiological Protection, ICRP Publication 55, Annals of the ICRP 20 (1), Pergamon Press, Elmsford, New York.

ICRP (1991). International Commission on Radiological Protection. 1990 Recommendations of the International Commission on Radiological Protection, ICRP Publication 60, Annals of the ICRP, 21 (1-3), Pergamon Press, Elmsford, New York.

Ippolito, P.M. and RA. Ippolito, "Measuring the Value of Life Saving from Consumer Reactions to New Information," Lournal of Public Economics 25, 1984, pp. 53-81

Ives, D., Thieme, $M$. and Kemp, R, "The Statistical Value of Life and Safety Investment," Norwich, Environmental Risk Assessment Unit, University of East Anglia, Research Report No. 13, 1993.

Jondrow, J., M. Bowes, and R Levy, "The Optimal Speed Limit," Economic Inquiry 21(3), 1983, pp. 325-336.

Jones-Lee, M.W., "The Value of Life: An Economic Analysis, University of Chicago Press, Chicago, Illinois, 1976.

Jones-Lee, M.W., "The Economics of Safety and Physical Risk," Basil Blackwell Ltd., Oxford, England, 1989.

Jones-Lee, M.W., M. Hammerton, and P.R. Philips, "The Value of Safety: Results of a National Sample Survey," Economic Journal 95(March), 1985, pp. 49-72.

Kathren, R, F. Masse, K. Mossman, G. Roessler, and $K$. Schiager, "Scientific and Public Issues Committee Position Statement: Radiation Dose Limits for the General Public," The Health Physics Society's Newsletter, Volume XXI, Number 5, May 1993.

Kniesner, T.J. and Leeth, J.D., "Compensating Wage Differentials for Fatal Injury Risk in Australia,
Japan, and the United States," Lournal of Risk and Uncertainty, 4(1), 1991, pp. 75-90.

Landefeld, J. S., "Control of New Materials with Carcinogenic Potential: An Economic Analysis," Unpublished Ph.D. dissertation, University of Maryland, College Park(MD), 1979.

Landefeld, J. S. and E.P. Seskin, "The Economic Value of Life: Linking Theory to Practice," American Journal of Public Health 72(6), 1982, pp. 550-566.

LeFaure, C., J. Lochard, C. Schieber, and T. Schneider, "Reference Monetary Value System for the Man Sievert: Equity and Time Dimensions," Draft paper for Health Physics, 1993.

Leigh, J. P., "Gender, Firm Size, Industry and Estimates of the Value-of-Life," Lournal of Health Economics 6, 1987, pp. 255-273.

Leigh, J. P. and R.N. Folsom, "Estimates of the Value of Accident Avoidance at the Job Depend on the Concavity of the Equalizing Differences Curve," The Quarterly Review of Economics and Business 24(1), 1984, pp. 56-66.

Maclean, A.D., The Value of Public Safety: Results of a Pilot-Scale Survey, London Home Office Scientific Advisory Branch, London, U.K, 1979.

Marin, A., "The Cost of Avoiding Death - Nuclear Power, Regulation and Spending on Safety," The Royal Bank of Scotland Review, V. 157, March 1988, pp. 20-36.

Marin, A. and G. Psacharopoulos, "The Reward for Risk in th Labor Market: Evidence from the United Kingdom and a Reconciliation with Other Studies," Journal of Political Economy 90(4), 1982, pp. 827-853.

Mattsson, B., "The Price of our Security," The Swedish National Audit Bureau, Stockholm, Sweden, 1990 (in Swedish). 
Melinek, S.J., "A Method of Evaluating Human Life for Economic Purposes," Accident Analysis and Prevention 6, 1974, pp. 103-114.

Miller, T.R, "Willingness to Pay Comes of Age: Will the System Survive," Northwestern University Law Review, Vol. 83, No. 4, Summer 1989.

Miller, T.R., "The Plausible Range for the Value of Life - Red Herrings Among the Mackerel," Lournal of Forensic Economics 3(3), 1990, pp. 17-39.

Miller, T.R. and J. Guria, "The Value of Statistical Life in New Zealand," unpublished, Report to the New Zealand Ministry of Transport, Land Transport Division, cited by Miller (1990).

Moore, M.J. and W.K Viscusi, "Doubling the Estimated Value of Life: Results Using New Occupational Fatality Data," Lournal of Policy Analysis and Management 7(3), 1988a, pp. 476. 490.

Moore, M.J. and W.K. Viscusi, "The QuantityAdjusted Value of Life," Economic Inquiry 26(3), 1988b, pp. 369-388.

Moore, M.J. and W.K. Viscusi, "Discounting Environmental Health Risks: New Evidence and Policy Implications," Lournal of Environmental Economics and Management, 18(2), pt. 2: S51-S62, 1990a.

Moore, M.J. and W.K Viscusi, "Models for Estimating Discount Rates for Long-Term Health Risks Using Labor Market Data," Lournal of Risk and Uncertainty, 3(4), 1990b, pp. 381-402.

Morrall, J.F., III, "A Review of the Record," Repulation, 10(2): 13-24, 1986, pp. 30-34.

Mubayi, V., G. Anandalingam, L. Neymotin, and V. Sailor, "Cost-Benefit Considerations in Regulatory Analysis," Revised Draft, Brookhaven National Laboratory, Safety and Risk Evaluation Division, Department of Advanced Technology, October 1992, in press.
National Safety Council, "Accident Facts," 1993 Edition, Itasca, Illinois, 1993.

New York Times, "A Bleak U.S. Report on KidneyFailure Patients," New York City, New York, November 4, 1993, p. A17.

NCRP (1987). National Council on Radiation Protection and Measurements. "Recommendations on Limits for Exposure to Ionizing Radiation," NCRP Report 91, Bethesda, Maryland.

NCRP (1989). National Council on Radiation Protection and Measurements. "Exposure of the U.S. Population from Occupational Radiation," NCRP Report No. 101, Bethesda, Maryland.

NCRP (1993). National Council on Radiation Protection and Measurements. "Limitation of Exposure to Ionizing Radiation," NCRP Report No. 116. Bethesda, Maryland.

Nicholson, W.J. and P.J. Landrigan, "Quantitative Assessment of Lives Lost Due to Delay in the Regulation of Occupational Exposure to Benzene," Environmental Health Perspectives, 82, 1989, pp. 185-188.

NRPB (1980). "Cost Benefit Analysis in the Optimisation of Protection of Radiation Workers: A Consultative Document," National Radiation Protection Board, Chilton, Didcot, Oxfordshire, Her Majesty's Stationery Office, London.

NRPB (1984). "Small Radiation Doses to Members of the Public," National Radiation Protection Board, Chilton, Didcot, Oxfordshire, Rep. ASP 7, Her Majesty's Stationery Office, London.

NRPB (1986). "Cost Benefit Analysis in the Optimisation of Radiological Protection," Advice given by the National Radiological Protection Board in compliance with the direction of the Health Ministers dated 19 August 1977, in relation to radiological protection matters. 
NRPB (1990). "Patient Dose Reduction in Diagnostic Radiology." Doc. NRPB 1, No. 3.

NRPB (1993a). "National Radiation Protection Board Statement on the 1990 Recommendations of the International Commission on Radiological Protection," Doc. NRPB, 4, No. 1, pp. 1-5.

NRPB (1993b). "1990 Recommendations of the International Commission on Radiological Protection, Recommendations for the Practical Application of the Board's Statement," prepared by R.H. Clarke, F.A. Fry, J.W. Stather, and G.A.M. Webb, Doc. NRPB, 4., No. 1, pp. 7-22.

NRPB (1993c). "Occupational Exposure: Guidance on the 1990 Recommendations of ICRP," prepared by A.D. Wrixon, J.R. Croft, A.P. Hudson, and J.D. Robb, Doc. NRPB, 4, No. 2, 1-26, 1993 c.

NRPB (1993d). "Public Exposure: Guidance on the 1990 Recommendations of ICRP," prepared by M.E. Morrey, C.A. Robinson, J.R. Simmonds, S.M. Haywood, and J.R. Cooper, Doc. NRPB, 4, No. 2 , pp. 27-41.

NRPB (1993e). "Values of Unit Collective Dose for Use in the 1990s," prepared by J.D. Robb and G.A.M. Webb, Doc. NRPB 4, No. 2, pp. 75-80.

NRPB (1993f). "Estimates of Late Radiation Risks to the U.K Population." Prepared by C.R Muirhead, R Cox, J.W. Stather, B.H. MacGibbon, A.A. Edwards, and R.G.E. Haylock, Doc. NRPB 4, No. 4, pp. 15-157.

Olson, C.A., "An Analysis of Wage Differentials Received by Workers on Dangerous Jobs," lournal of Human Resources 16, 1981, pp. 167-185.

Page, S.D., "The Science and Policy of EPA's Radon Program," The Health Physics Society's Newsletter, Volume XXI, Number 5, May 1993.

Parsonage, M. and H. Neuburger, "Discounting and Health Benefits," Health Economics, Vol. 1, pp. 71 79, 1992.
Persson, U., "The Value of Risk Reduction: Results of a Swedish Sample Survey," The Swedish Institute for Health Economics, University of Lund, Lund, Sweden, 1989.

Persson, U. and M. Cedervall, "The Value of Risk Reduction: Results of a Swedish Survey," The Swedish Institute for Health Economics, IHE Working Paper, The University of Lund, Lurd, Sweden, 1991.

Ramsay, I. and A.H. Khan, "Assigning a Monetary Value to the Person-Sievert," HSD-HP-92-35, unpublished, Ontario Hydro, Pickering, Ontario, Canada, 1992.

Robb, J.D., "Valuing Radiation Detriment for Optimisation Purposes," NRPB Radiological Protection Bulletin, No. 110, March 1990.

Robb, J.D. and Wrixon, A.D., "Revised Estimates of the Monetary Value of Collective Dose," NRPB. M157, 1988.

Royal Society, "Risk: Analysis, Perception and Management," Royal Society, London, 1992.

Russell, J.G.B. and G.A.M. Webb, "Valuing the Man-Sievert in X-ray Diagnosis," British lournal of Radiology, 60, 681 (1987).

Schiager, KJ., "Radon: Risk and Reason," Published in The Health Physics Society's Newsletter, Volume XVIII, No. 10, October 1990.

Smith, A. (1776). "The Wealth of Nations," reprint edition, Modern Library, New York, 1937.

Smith, R.S., "The Feasibility of an 'Injury Tax' Approach to Occupational Safety, Law and Contemporary Problems," 38(4), 1974, pp. 730-744.

Smith, RS., The Occupational Safety and Health Act: Its Goals and Achievement, American Enterprise Institute, Washington (DC), 1976.

Smith, V.K., "The Role of Site and Job Characteristics in Hedonic Wage and Models," 


\section{References}

Lournal of Urban Economics 13(3), 1983, pp. 296 . 321 .

Smith, V. K and C.C.S. Gilbert, "The Implicit Valuation of Risks to Life: A Comparative Analysis," Economic Letters 16, 1984, pp. 393-399.

Swedish Radiation Protection Institute, "The Monetary Value of Collective Dose Reduction ( $\alpha$ value)," Statement from meeting of the Nordic Radiation Protection Authorities (Denmark, Finland, Iceland, Norway, and Sweden) at Reykjavik, June 14, 1991.

Thaler, $R$ and $S$. Rosen, "The Value of Saving a Life: Evidence from the Market," in Nestor E. Terleckyj (ed.), Household Production and Consumption, National Bureau of Economic Research, New York, 1976.

Travis, C.C., S.A. Richter, E.A.C. Crouch, R Wilson, and E.D. Klema, "Cancer Risk Management," Environ. Sci. Technol, Vol. 21, No. 5, 1987a, pp- 415-420

Travis, C.C., S. Richter Pack, and A. Fisher, "CostEffectiveness as A Factor in Cancer Risk Management," Environment International, Vol. 13. 1987b, pp. 469-474.

UKAEA, Authority Code of Practice, Radiological Guidelines for the Design and Operation of UKAEA Plant, SRD R456, UKAEA June, 1987.

USBC (1992). U.S. Burean of Census, Statistical Abstracts of the United States, 12th Edition, Washington, D.C.

U.S. Environmental Protection Agency, "Technical Support Document for the 1992 Citizen's Guide to Radon," Office of Radiation and Indoor Air, Washington, D.C. (EPA400-R-92-911), May 1992.

USNRC, 10 CFR 50, Appendix I, "Numerical Guides for Design Objectives and Limiting Conditions for Operation to Meet the Criterion "As Low As Is Reasonably Achievable," For Radioactive Material in Light-Water-Cooled Nuclear Power
Reactor Effluents," 40 FR 19439, May 5, 1975; amended 40 FR 40516, September 4, 1975; 40 FR 33029, December 19, 1975.

USNRC, 10 CFR 20, "Standards for Protection Against Radiation," Federal Register Vol. 56, No. 98, May 21, 1991, pp. 23390-23474.

USNRC, "ALARA Levels for Effluents from Materials Facilities," Regulatory Guide 8.37, July 1993.

Viscusi, W. K., "Labor Market Valuations of Life and Limb: Empirical Evidence and Policy Implications," Public Policy (Summer), 1978a, pp. 359-386.

Viscusi, W.K., "Wealth Effects and Earnings Premiums for Job Hazards," Review of Economics and Statistics 60(3): 408-416, $1978 \mathrm{~b}$.

Viscusi, W.K., "Union Labor Market Structure, and the Welfare Implications of the Quality of Work," Lournal of Labor Research 1(1), 1980, pp. 175-192.

Viscusi, W.K, "Occupational Safety and Health Regulation: Its Impact and Policy Alternatives," Research in Public Analysis and Management 2. 1981, pp. 281-299.

Viscusi, W. K, Fatal Tradeoffs - Public and Private Responsibilities for Risk, Oxford University Press, 1992.

Viscusi, W.K. W.A. Magat, and J. Huber, "Pricing Environmental Health Risks: Survey Assessments of Risk-Risk and Risk-Dollar Trade-offs," Estimating and Valuing Morbidity in a Policy Context: Proceedings of June 1989 AERE Workshop, U.S. Environmental Protection Agency, Washington (DC), 1989.

Viscusi, W.K, W.A. Magat, and J. Huber, "Pricing Environmental Health Risks: Survey Assessments of Risk-Risk and Risk-Dollar Tradeoffs, "Lournal of Environmental Economics and Management 201: 32-57, 1991. 
Viscusi, W. K. and M. Moore, "The Quality. Adjusted Value of Life,' Economic Inquiry 26, 1988, pp. 369-388.

Viscusi, W.K and M.J. Moore, "Rates of Time Preference and Valuations of the Duration of Life," Lournal of Public Economics 38, 1989, pp. 297-317.

Webb, G.A.M., "The Requirement to Keep Radiation Exposures as Low as Reasonably Achievable (ALARA). Proof of Evidence to the Sizewell 'B' Inquiry," National Radiological Protection Board, Chilton, Didcot, Oxfordshire, Rep. NRPB/P/3 (October 1984) and Rep. NRPB/P/3 ADD 1 (December 1984).

Winston, C. and F. Mannering, "Consumer Demand for Automobile Safety: New Evidence on the Demand for Safety and the Behavioral Response to Safety Regulation," American Economic Review 74(2), 1984. 


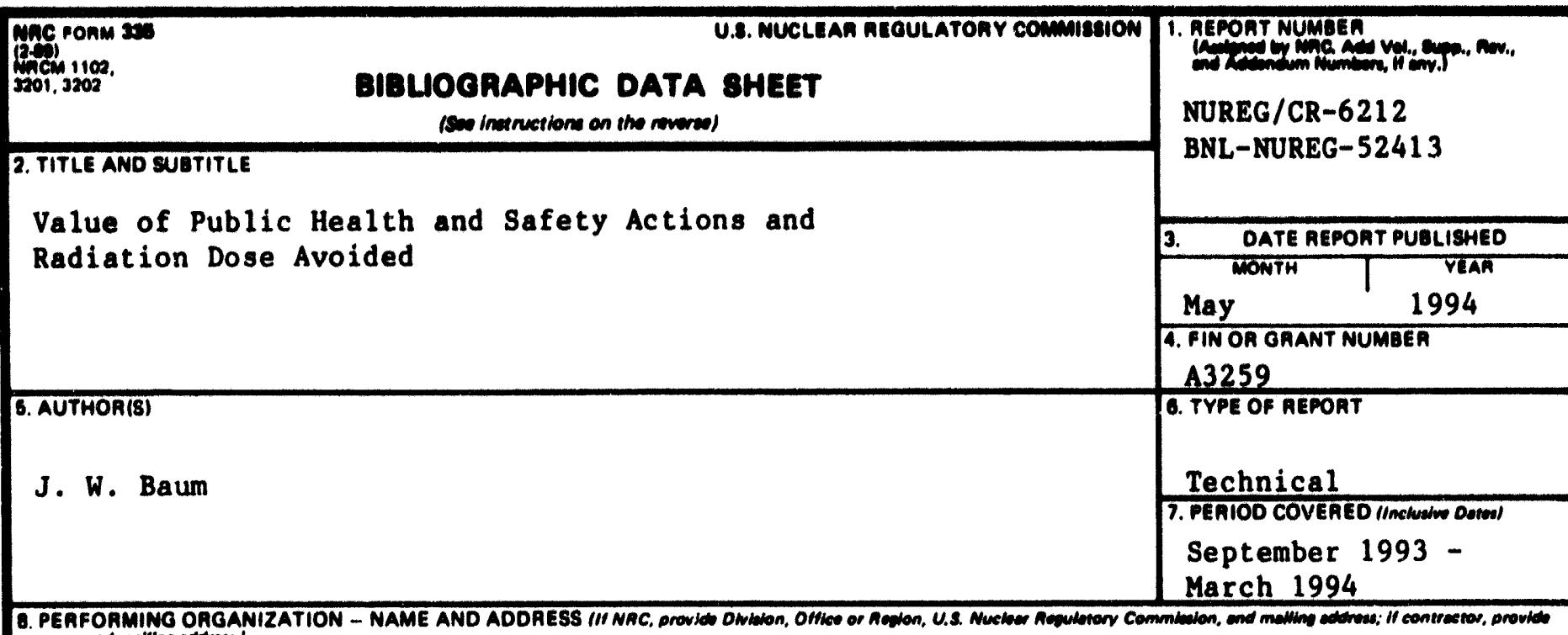

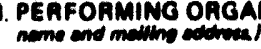

Brookhaven National Laboratory

Upton, NY 11973-5000

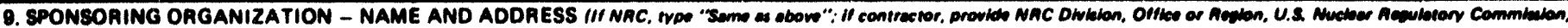
and maithn odonsen,

Division of Regulatory Applications

Office of Nuclear Regulatory Research

U.S. Nuclear Regulatory Commission

Hashington. DC 20555-0001

10. SUPPLEMENTAAY NOTES

11. ABSTRACT (200 montw or mal)

The values judged best to reflect the willingness of society to pay for the avoldance or reduction of risk were deduced from studies of costs of health care, transportation safety, consumer product safety, government agency actions, wage-risk compensation, consumer behavior (market) studies, and willingness-to-pay surveys. The results ranged from $\$ 1,400,000$ to $\$ 2,700,000$ per life saved. Applying the mean of these values $(\$ 2,100,000)$ and the latest risk per unit dose coefficients used by the ICRP (1991), which take into account risks to the general public, including genetic effects and nonfatal cancers, yields a value of dose avoided of $\$ 750$ to $\$ 1,500$ per person-cSv for public exposures. The lower value applies if adjustments are made for years of life lost per fatality. A nominal value of $\$ 1,000$ per person-cSv seems appropriate in light of the many uncertainties involved in deducing these values.

These values are consistent with values recommended by several European countries for individual doses in the region of $1 \mathrm{mSv} / \mathrm{y}(100 \mathrm{mrem} / \mathrm{y})$. Below this dose rate, most countries have values a factor of 7 to 10 lower, based on the assumption that society is less concerned with fatality risks below about $10^{-4} / \mathrm{y}$.

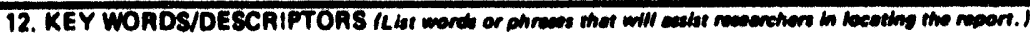

Public Health - Radiation Doses; Public Health - Values; Radiation Protection - Cost; Safety - Cost; Dose Limits; Economis; ICRP; Occupat Ional Safety; Recommendat Ions; Risk Assessment; Safety Standards; US NRC; BNL

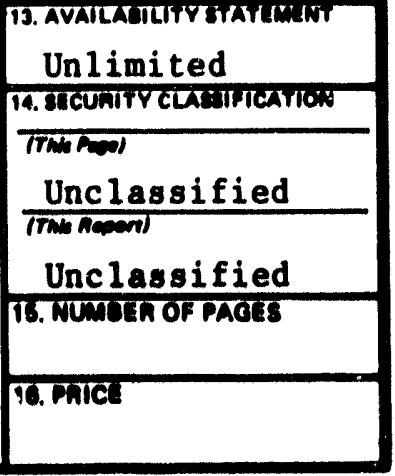



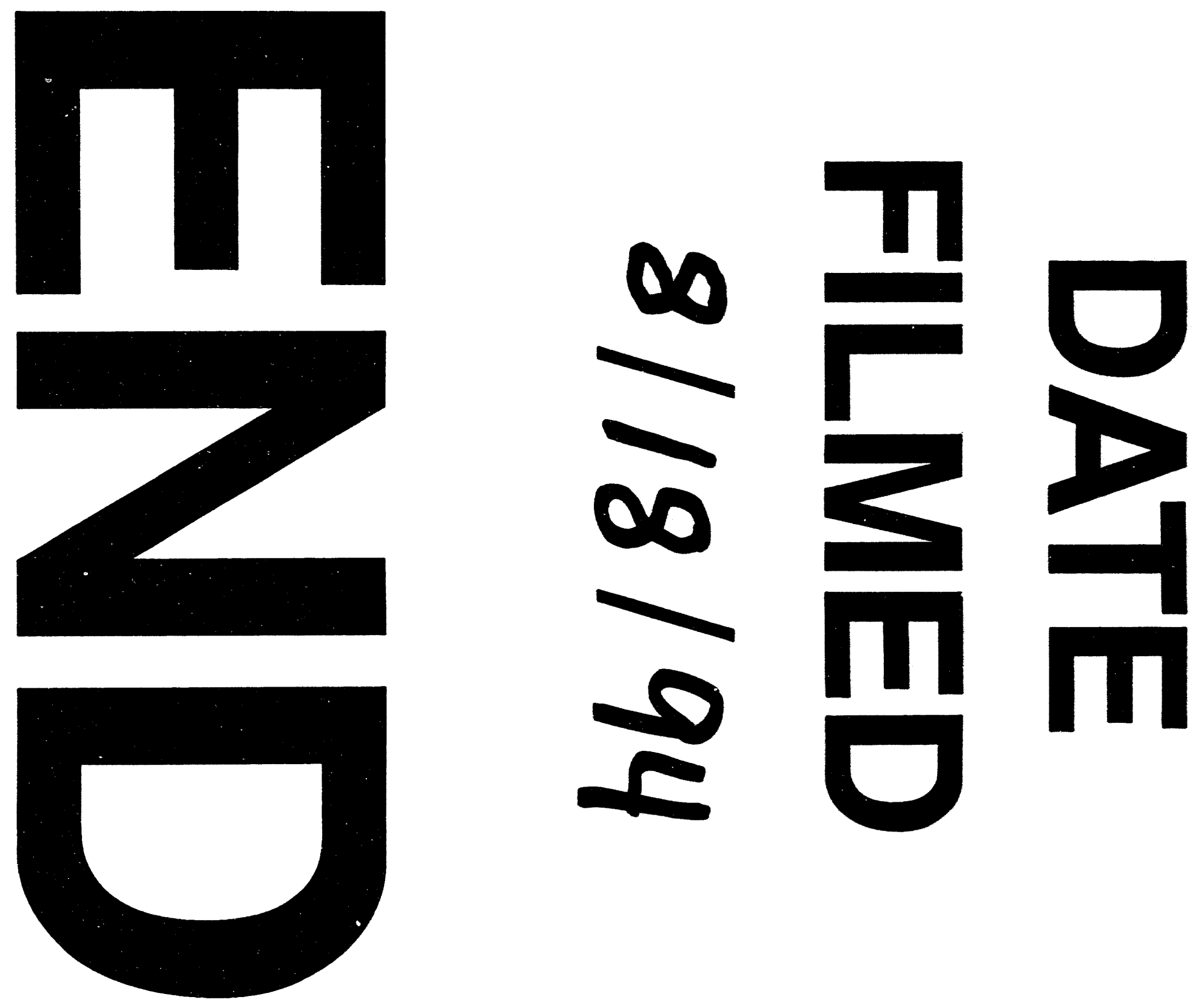
